

\section{NOAA TECHNICAL REPORTS}

\section{National Marine Fisheries Service, Circulars}

The major responsibilities of the National Marine Fisheries Service (NMFS) are to monitor and assess the abundance and geographic distribution of fishery resources, to understand and predict fluctuations in the quantity and distribution of these resources, and to establish levels for optimum use of the resources. NMFS is also charged with the derelopment and implementation of policies for managing national fishing grounds, development and enforcement of domestic fisheries regulations, surveillance of foreign fishing off United States coastal waters, and the development and enforcement of international fishery agreements and policies. NMFS also assists the fishing industry through marketing service and economic analysis programs, and mortgage insurance and ressel construction subsidies. It collects, analyses, and publishes statistics on various phases of the industry.

The NOAA Technical Report NMFS CIRC series continues a series that has been in existence since 1941. The Circulars are technical publications of general interest intended to aid conservation and management. Publications that review in considerable detail and at a high technical level certain broad areas of research appear in this series. Technical papers originating in economics studies and from management investigations appear in the Circular series.

NOAA Technical Reports NMFS CIRC are available free in limited numbers to governmental agencies, both Federal and State. They are also available in exchange for other scientific and technical publications in the marine sciences. Individual copies may be obtained (unless otherwise noted) from NOAA Publications Section, Rockville, Md. 20852. Recent Circulars are:

315. Synopsis of biological data on the chum salmon, Oncorhynchus keta (Walbaum) 1792. By Richard G. Bakkala. March 1970, iii + 89 pp., 15 figs., 51 tables.

319. Bureau of Commercial Fisheries Great Lakes Fishery Laboratory, Ann Arbor, Michigan. By Bureau of Commercial Fisheries. March 1970, 8 pp., 7 figs.

330. EASTROPAC Atlas: Vols. 4, 2. Catalog No. I $49.4: 330 /$ (vol.) 11 vols. ( $\$ 4.75$ each). Available from the Superintendent of Documents, Washington, D.C. 20402.

331. Guidelines for the processing of hot-smoked chub. By H. L. Seagran, J. T. Graikoski, and J. A. Emerson. January 1970, iv +23 pp., 8 figs., 2 tables.

332. Pacific hake. (12 articles by 20 authors.) March 1970, iii + 152 pp., 72 figs., 47 tables.

333. Recommended practices for vessel sanitation and fish handling. By Edgar W. Bowman and Alfred Larsen. March 1970 , iv + 27 pp., 6 figs.

335. Progress report of the Bureau of Commercial Fisheries Center for Estuarine and Menhaden Research, Pesticide Field Station, Gulf Breeze, Fla., fiscal year 1969. By the Laboratory staff. August 1970, iii + 33 pp., 29 figs., 12 tables.

336. The northern fur seal. By Ralph C. Baker, Ford Wilke, and C. Howard Baltzo. April 1970, iii + 19 pp., 13 figs.

337. Program of Division of Economic Research, Bureau of Commerecial Fisheries, fiscal year 1969. By Division of Economic Research. April 1970, iii +29 pp., 12 figs., 7 tables.
338. Bureau of Commercial Fisheries Biological Laboratory, Auke Bay, Alaska. By Bureau of Commercial Fisheries. June 1970, 8 pp., 6 figs.

339. Salmon research at Ice Harbor Dam. By Wesley J. Ebel. April 1970, 6 pp., 4 figs.

340. Bureau of Commercial Fisheries Technological Laboratory, Gloucester, Massachusetts. By Bureau of Commercial Fisheries. June 1970, 8 pp., 8 figs.

341. Report of the Bureau of Commercial Fisheries Biological Laboratory, Beaufort, N.C., for the fiscal year ending June 30,1968 . By the Laboratory staff. August 1970 , iii +24 pp., 11 figs., 16 tables.

342. Report of the Bureau of Commercial Fisheries Biological Laboratory, St. Petersburg Beach, Florida, fiscal year 1969. By the Laboratory staff. August 1970, iii +22 pp., 20 figs., 8 tables.

343. Report of the Bureau of Commercial Fisheries Biological Laboratory, Galveston, Texas, fiscal year 1969. By the Laboratory staff. August 1970, iii + 39 pp., 28 figs., 9 tables.

344. Bureau of Commercial Fisheries Tropical Atlantic Biological Laboratory progress in research 1965-69, Miami, Florida. By Ann Weeks. October 1970 , iv + 65 pp., 53 figs.

346. Sportsman's guide to handling, smoking, and preserving Great Lakes coho salmon. By Shearon Dudley, J. T. Graikoski, H. L. Seagran, and Paul M. Earl. September 1970 , iii +28 pp., 15 figs.

347. Synopsis of biological data on Pacific ocean perch, Sebastodes alutus. By Richard L. Major and Herbert H. Shippen. December 1970, iii +38 pp., 31 figs., 11 tables.

Continued on inside back cover. 


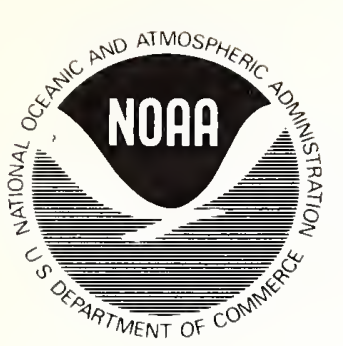

U.S. DEPARTMENT OF COMMERCE

Frederick B. Dent, Secretary

NATIONAL OCEANIC AND ATMOSPHERIC ADMINISTRATION

Robert M. White, Administrator

NATIONAL MARINE FISHERIES SERVICE

Robert W. Schoning, Director

\section{NOAA Technical Report NMFS CIRC-378}

\section{Marine Flora and Fauna of \\ the Northeastern United States. \\ Protozoa: Ciliophora}

ARTHUR C. BORROR 


\section{FOREWORD}

This issue of the "Circulars" is part of a subseries entitled "Marine Flora and Fauna of the Northeastern United States." This subseries will consist of original, illustrated, modern manuals on the identification, classification, and general biology of the estuarine and coastal marine plants and animals of the Northeastern United States. Manuals will be published at irregular intervals on as many taxa of the region as there are specialists willing to collaborate in their preparation.

The manuals are an outgrowth of the widely used "Keys to Marine Invertebrates of the Woods Hole Region," edited by R. I. Smith, published in 1964, and produced under the auspices of the Systematics-Ecology Program, Marine Biological Laboratory, Woods Hole, Mass. Instead of revising the "Woods Hole Keys," the staff of the SystematicsEcology Program decided to expand the geographic coverage and bathymetric range and produce the keys in an entirely new set of expanded publications.

The "Marine Flora and Fauna of the Northeastern United States" is being prepared in collaboration with systematic specialists in the United States and abroad. Each manual will be based primarily on recent and ongoing revisionary systematic research and a fresh examination of the plants and animals. Each major taxon, treated in a separate manual, will include an introduction, illustrated glossary, uniform originally illustrated keys, annotated check list with information when available on distribution, habitat, life history, and related biology, references to the major literature of the group, and a systematic index.

These manuals are intended for use by biology students, biologists, biological oceanographers, informed laymen, and others wishing to identify coastal organisms for this region. In many instances the manuals will serve as a guide to additional information about the species or the group.

Geographic coverage of the "Marine Flora and Fauna of the Northeastern United States" is planned to include organisms from the headwaters of estuaries seaward to approximately the $200-\mathrm{m}$ depth on the continental shelf from Maine to Virginia, but may vary somewhat with each major taxon and the interests of collaborators. Whenever possible representative specimens dealt with in the manuals will be deposited in reference collections of the Gray Museum, Marine Biological Laboratory, and other universities and research laboratories in the region.

After a sufficient number of manuals of related taxonomic groups have been published, the manuals will be revised, grouped, and issued as special volumes. These volumes will thus consist of compilations of individual manuals within phyla such as the Coelenterata, Arthropoda, and Mollusca, or of groups of phyla. 


\section{CONTENTS}

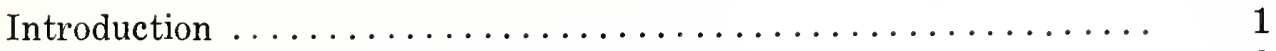

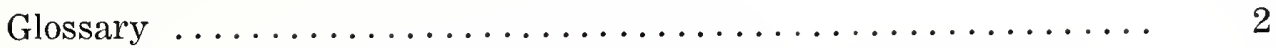

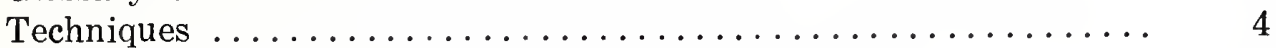

Key primarily to families of the Ciliophora .............. 6

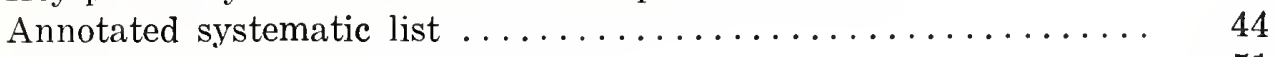

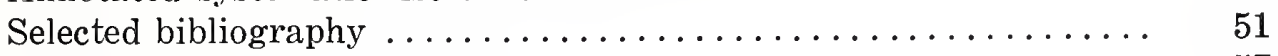

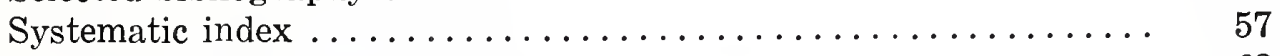

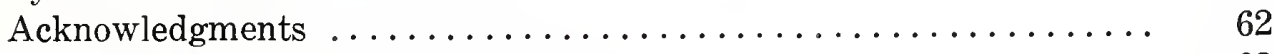

Coordinator's comments ...................... 62

The National Marine Fisheries Service (NMFS) does not approve, recommend or endorse any proprietary product or proprietary material mentioned in this publication. No reference shall be made to NMFS, or to this publication furnished by NMFS, in any advertising or sales promotion which would indicate or imply that NMFS approves, recommends or endorses any proprietary product or proprietary material mentioned herein, or which has as its purpose an intent to cause directly or indirectly the advertised product to be used or purchased because of this NMFS publication. 



\title{
MARINE FLORA AND FAUNA OF THE NORTHEASTERN UNITED STATES. Protozoa: Ciliophora
}

\author{
ARTHUR C. BORROR
}

\begin{abstract}
This manual includes an introduction on the general biology, an illustrated key, an annotated systematic list, a selected bibliography, and an index to the marine ciliated Protozoa of coastal and estuarine waters of New England. The key facilitates identification to family of nonencysted, nondividing marine ciliates at any stage in the life cycle.
\end{abstract}

\section{INTRODUCTION}

This manual is a guide to the families of marine ciliated Protozoa of coastal and estuarine waters of New England. It includes ciliates to be encountered not only in areas of high salinity but also in the upper reaches of estuaries where the water is brackish. It is intended for use by a broad audience, hence is artificial (order not necessarily parallel to phylogenetic sequence), and is stripped of unnecessary technical terms. The key facilitates identification to family of nonencysted, 'nondividing marine ciliates at any stage in the life cycle.

Some families are omitted from this key because they are represented only by ciliates living in fresh water or in soil. These include Actinobolinidae, Amphibothrellidae, Astylozoidae, Bursariidae, Dendrocometidae, Discomorphellidae, Glaucomidae, Marynidae, Microthoracidae, Ophrydiidae, Reichenowellidae, Spirozonidae, Trichospiridae, and Urocentridae. Families that are represented solely by ciliates endozoic in nonmarine hosts are also omitted. These include Buetschiliidae, Clevelandellidae, Cyathodiniidae, Gyrocorythidae, Isotrichidae, Maupasellidae, Paraisotrichidae, Plagiotomidae, Pycnotrichidae, and Thigmocomidae.

${ }^{1}$ Department of Zoology, Spaulding Building University of New Hampshire, Durham, NH 03824.
In general, the families recognized in the key and genera included in each are those recognized by Corliss (1961); numerous exceptions based on more recent studies are noted in the Annotated Systematic List. Each family and most couplets are illustrated by line drawings.

Since a few characteristics (i.e., presence or absence of an undulating membrane) may be difficult to observe, some families key out in two different places. In such instances, the other couplet in which the family is named is indicated. When different genera within the same family key out in different places, the family name is followed by the words "in part."

Members of the subphylum Ciliophor'a, usually known as ciliates, are usually single celled with membrane-bound nuclei. Branching colonies occur in the Vorticellidae and Epistylididae (Peritrichida) and in the Dendrosomatidae and Ophryodendridae (Suctorida). Colonies in linear series occur in the Intoshellinidae, Hoplitophryidae, and Opalinopsidae.

Most ciliates have two kinds of nuclei, that is, with one to many micronuclei and one to many macronuclei. However, members of the family Stephanopogonidae have only one type of nucleus.

The micronucleus is usually diploid, less than $5 \mu \mathrm{m}$ in diameter, and usually visible only in stained preparations. Ciliates in strains of some species are amicronucleate.

The macronucleus is usually hyperpolyploid 
(contains many sets of chromosomes). It may be single (compact, ribbonlike, beaded, or branched) or separated into membrane-bound structures that typically reconsolidate prior to fission. Macronuclei of members of the Trache. locercidae, Loxodidae, and Geleiidae have extensive Feulgen-negative areas, cannot replicate, and. in some cases, have been shown to be diploid.

Within the Ciliophora there is wide variation in the arrangement of the cilia, and this forms the basis for classification. Cilia are absent at some stages of the life cycle of all members of the order Suctorida, many members of the family Sphenophryidae, and members of the genus Conidiophrys. Cilia may occur singly, in rows, bands, or ribbons, or may be grouped as compound structures (cirri, undulating membranes, and membranelles). Ciliates that lack cilia during much of their life cycle, however, possess other characteristics of the group.

Except for members of the Suctorida, Astomatida, and some members of the order Thigmotrichida, all ciliates possess a permanent opening, the cytostome, through which food is ingested.

All ciliates are heterotrophic and do not exhibit ameboid locomotion. In binary fission, the division plane bisects the ciliary rows, dividing the cell into anterior and posterior daughter cells.

\section{GLOSSARY}

The following terms are used in this key to describe the anatomy of marine ciliates. Commonly used terms are illustrated in Figures 1-5. More complete definitions of structures are given by Corliss (1959).

Aboral Surface opposite that on which the cytostome or buccal cavity occurs.

Buccal cavity A depression in the surface of the cell containing cilia that are differentiated from those of the general body surface and that are used in feeding. This cavity contains the cell mouth or cytostome (see Fig. 1).

Buccal cilia Cilia in the buccal cavity used in feeding. These cilia usually are organized into compound organelles, such as an undulating membrane or membranelles.

Ciliary row A linear series, usually longitudinal, of simple cilia (see Fig. 2, 3).
Cirrus A compound ciliary organelle polygonal in cross section, composed of several to dozens of individial cilia. These usually occur on the ventral surface of members of the order $\mathrm{Hy}$ potrichida and are used in locomotion (see Fig. 1).

Compound ciliaryorganelle Any structure such as a cirrus, undulating membrane or membranelle composed of many functionally united cilia.

Contractile vacuole A clear membrane-bound vesicle functioning in expulsion of water and accompanied by rhythmic changes in its diameter.

Cytopharyngeal rod Stiff fibrous structures lining the cytopharynx, often in a conical arrangement (see Fig. 3).

Cytopharynx That part of the cytoplasm immediately adjacent and internal to the cytostome and not ciliated (see Fig. 3).

Cytostome The cell mouth. This may be on the surface, in a vestibulum ciliated by the cilia of the general cell surface, or in a buccal cavity (see Fig. 5).

Fronto-ventral cirri Cirri arranged in scattered groups anterior to the transverse cirri.

Lorica A secreted chamber open at least at one end in which some ciliates live.

Marginal cirri Cirri arranged in longitudinal rows to the right and left of the ventral midline (see Fig. 1).

Membranelle A compound ciliary organelle composed of several closely set and parallel rows of cilia. They are associated with a buccal cavity and may function both in feeding and in locomotion (see Fig. 1).

Motile Capable of independent locomotion on or off the substratum.

Peniculus A compound ciliary organelle of the buccal cavity of some members of the order Hymenostomatida. It may consist of a band typically four cilia wide but many cilia in length, very compactly arranged (see Fig. 4).

Psammolittoral Living in interstices among sand grains.

Scopula A surface organelle that secretes the stalk in many sessile ciliates. Usually at one apex of the cell.

Sessile Generally incapable of locomotion. Usually attached to a substratum by a stalk or flattened sole, or wrapped around the bristle of some invertebrate. 

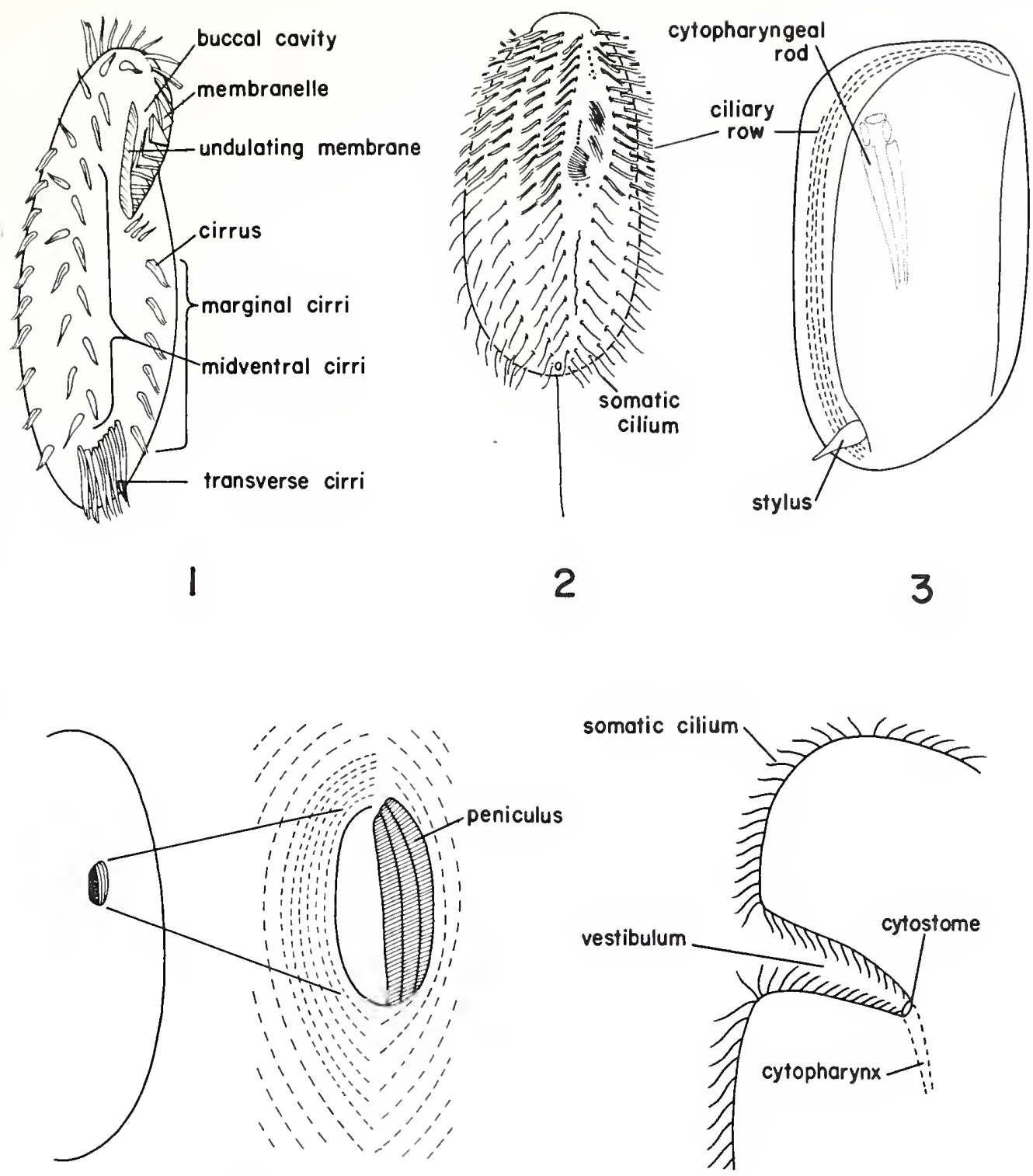

4

5

Figure 1.-Holosticha diademata, ventral aspect.

Figure 2.-Uronema sp., oral aspect.

Figure 3.-Dysteria sp., ventral aspect. Ciliary rows indicated by dash lines.

Figure 4.-Frontonia sp., oral aspect with region of buccal cavity enlarged in the diagram to the right.

Figure 5.-Diagram of a ciliate with a lateral vestibulum.

Simple cilium A cilium that emerges singly from the cell surface and is morphologically and functionally a unit.

Somatic cilia All kinds of simple and compound cilia of the general body surface, usually used in locomotion (see Fig. 2).

Stylus A posterior cirruslike extension of the cell surface in members of the Dysteriidae, resembling the posterior projection of some rotifers. It is a secretory organelle for temporary attachment (see Fig. 3).

Thigmotactic Capable of crawling along surfaces, and resisting removal from such surfaces. 
Tomite The stage in the life cycle of some ciliates which results from repeated divisions of a larger cell without any cell growth, such that the eventual cell is considerably smaller than the original cell.

Transverse cirri A group of five to many relatively large cirri near the posterior end of the body on the ventral midline (see Fig. 1).

Trophont The normal feeding adult stage of the life cycle of the ciliate.

Undulating membrane A compound ciliary organelle consisting of one or several closely set rows of cilia usually placed longitudinally along the right edge of the buccal cavity where it functions in feeding (see Fig. 1).

Vestibulum A depression of the cell surface bearing simple cilia used in feeding (see Fig. $5)$.

\section{TECHNIQUES}

Ciliated Protozoa occur in a wide variety of environments, wherever there are sufficient nutrients, moisture, and appropriate microhabitats. Ciliates can be observed easily by examining collections from tidal pools on rocky shores and marshes. They are particularly abundant both intertidally and subtidally in interstices among sand grains. Ciliates also reach great numbers among fine filaments of some green algae (i.e., Cladophora and Vaucheria). Wide-mouthed glass jars $\left(100-2,000 \mathrm{~cm}^{3}\right)$ make excellent container's for nonquantitative collecting of ciliates from such habitats. Add enough substratum to fill the container about one-third and an equal amount of water.

As soon as you can do so conveniently, distribute some of the material among several fingerbowls with varying proportions of substratum and water, to increase the variety of possible ciliates.

Ciliates may be concentrated from field samples by filtration, moderate centrifugation, and other separation methods such as electromigration (Hairston and Kellermann, 1964) and extraction with seawater ice (Uhlig, 1965).

To remove ciliates from interstices of mats of vegetation, filter them through two-ply cheesecloth, then concentrate them with Whatman \#1 filter paper. As this will retain all but the smallest organisms (less than $15 \mu \mathrm{m}$ width), the contents of the filter can be removed to a petri dish for examination. Series of filters containing nylon gauze of known mesh size (Nytex) allow separation of most metazoans and larger fragments of debris from the water containing ciliates.

Moderate centrifugation (5-20 min at 2,500 rpm) can also help to concentrate many ciliates. The speed or duration of centrifugation can be varied to correspond with the size and fragility of the organism.

Although most ciliates undergo sexual processes, they normally reproduce asexually and hence can be cultured to obtain additional specimens for further study. Cultures can be maintained in suitable covered containers. Addition of simple nutrients (i.e., rice grains, wheat grains, split peas, short dried lengths of grass stems) will increase the growth rate of the microflora on which many ciliates feed.

In addition to these simple methods there are many inorganic solutions and complex culture media available for maintaining mixed cultures of ciliates (see Kudo, 1966).

The couplets in this key are based on living material and assume sufficient microscopic resolution to allow visibility of the structures described. As the organisms are small, they must be examined with great care, and since living ciliates often move too rapidly to allow identification, it is necessary to slow them down. This is accomplished by removing sufficient water from the edge of the preparation to squeeze the animal gently between the slide and coverslip. As this may cause distortion and death of the cell, studies on living specimens should be augmented with stained preparations.

Observations of living individuals of ciliates can often be supplemented by appropriate fixation and staining procedures that allow resolution and differentiation of features difficult to see in life (i.e., nuclei, details of the cilia in the region of the cytostome). The simplest cytological methods easily employed in marine ciliates are variations of the iron hematoxylin method, the Feulgen nucleal reaction (both described by Kudo, 1966), and the nigrosin-mercuric chloride-Formalin technique (NMF method) (see Borror, 1968a, 1969).

The NMF method can be applied to fresh material rapidly, giving permanently stained cells in 10 or 15 min. The stain-affixative is mixed 
as needed and can be used repeatedly for at least a month if kept cool:

$\mathrm{HgCl}_{2}$, saturated aqueous, $10 \mathrm{ml}$

Glacial acetic acid, $2 \mathrm{ml}$

Formalin, conc., $2 \mathrm{ml}$

formol-nigrosin, 1-2 $\mathrm{ml}$ (depending upon intensity desired)

t-butanol, $10 \mathrm{ml}$.

The formol-nigrosin is mixed as follows:

Formalin, conc., $20 \mathrm{ml}$

nigrosin, soluble, $4 \mathrm{~g}$

distilled water, $100 \mathrm{ml}$.

The procedure for the NMF method is: Place a drop of a concentrated suspension of organisms on a clean slide and pipette onto it from a height of $2-3 \mathrm{~cm}$ a drop of stain-fixative. After a few seconds wash the culture fluid to the ends of the slide by additional drops of the stainfixative. Practically all the specimens will be fixed, stained, and attached to the slide, and after about $15 \mathrm{sec}$ the preparation may be dehydrated, cleared, and covered. Ciliary organelles generally will appear black against a gray background, cytopharyngeal rods, isolated dorsal cilia, granules between ciliary rows, compound buccal cilia, surface ridges, and general surface morphology are demonstrated (Borror, 1968a). Highly contractile ciliates sometimes can be prepared by this method following their relaxation in $8 \%$ $\mathrm{MgCl}_{2}$; extremely fragile ciliates often can be prepared by this method following preliminary fixation in Champy's fluid (Borror, 1969).
In addition, most ciliate specialists use one or both of the following methods: the ChattonLwoff technique (sometimes called the French silver method or the wet silver method) and the protargol (or silver proteinate) method (Corliss, 1953; Tuffrau, 1967a). The body form is particularly well preserved with the latter methods. Both methods require several hours for preparation and careful attention to the variables of time and temperature, and are part of the repertoire of the specialist. Although not necessary for the use of this key generally, the Chatton-Lwoff technique is particularly desirable for identification of members of the Hymenostomatida, whose buccal structures are difficult to discern in life. This technique also demonstrates basal bodies of cilia and other cortical features such as cytostome, pore of the contractile vacuole, cell anus, and fiberlike "silver lines" that apparently are places of contiguity of cortical membrane systems. The protargol method stains cilia and associated fibrillar systems as well as nuclei and, in association with the Chatton-Lwoff technique, is particularly useful in developmental studies.

Further information on the use of the microscope for examination of ciliates, preparation of slides with both fresh and permanent material, as well as additional cytological techniques, can be found in Kudo (1966). In the hands of a nonspecialist, a small amount of $10 \%$ Methocel in seawater greatly facilitates study of living ciliates and does not prevent subsequent staining with acidified methyl green. 


\section{KEY PRIMARILY TO FAMILIES OF THE CILIOPHORA}

1 Cilia distributed uniformly, except at the anterior or posterior ends of the cell, or at the vestibulum or buccal cavity. Cilia in rows. Cytostome present or absent.

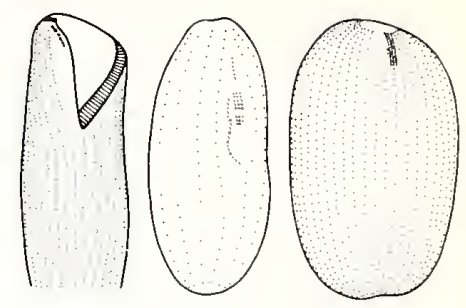

1 Cilia reduced in number, often nonuniform in distribution, leaving nonciliated surfaces. Cytostome present or absent. 54
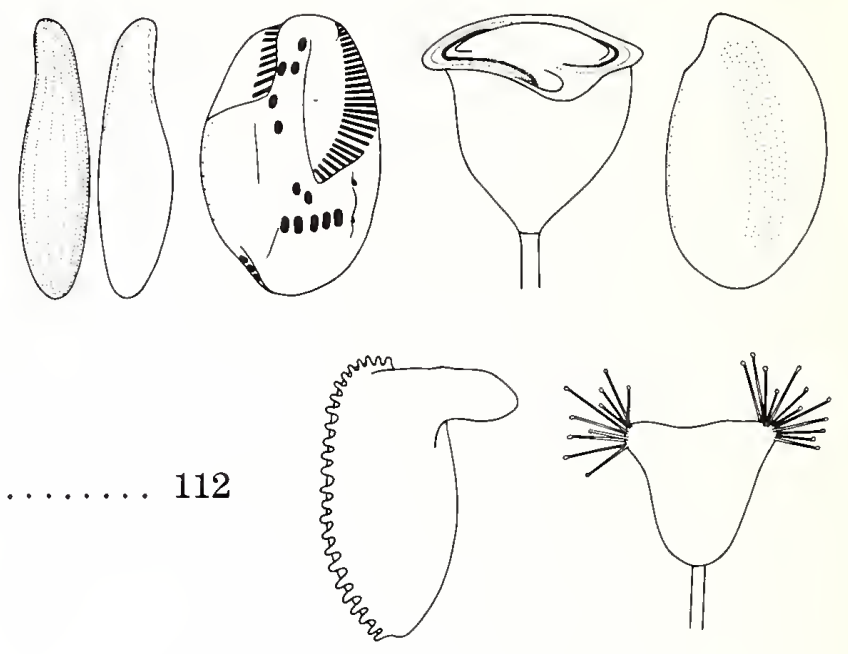

2 (1) Cilia all simple, not forming compound, membranous, or synchronous units. (Note: membranellelike groups of cilia occur on the general cell surface of the ciliates
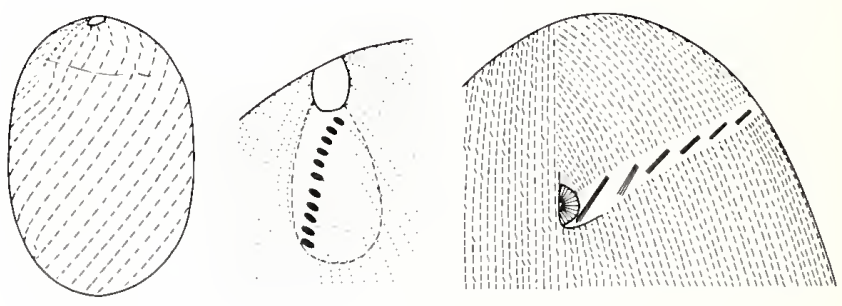
Placus socialis, Prorodon mimeticus, and member of the Family NASSULIDAE).

2 (1) Compound cilia present as cirri, undulating membranes, peniculi, or membranelles, functioning synchronously, in feeding and/or locomotion.
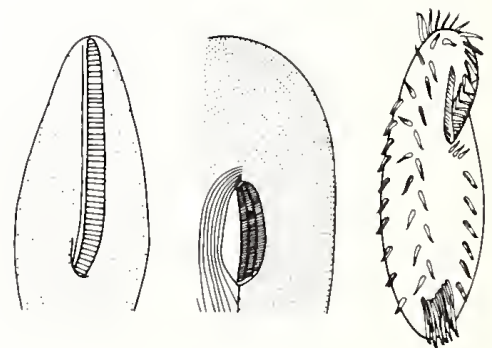
3 (2) Cytostome apical, lateral, or ventral on cell surface or in depression. Free-living or endocommensal. ...

3 (2) Cytostome absent. Cell oval-elongate, living in various invertebrates.

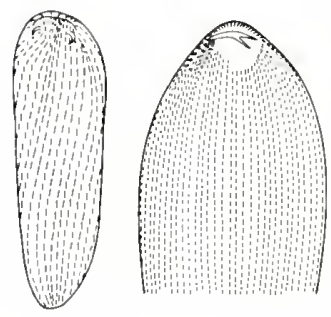

4 (3) Cytostome apical; circular or slitlike........... 5

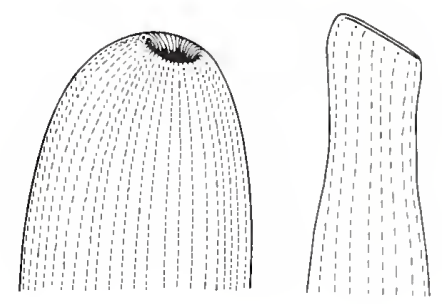

4 (3) Cytostome lateral or ventral. 11

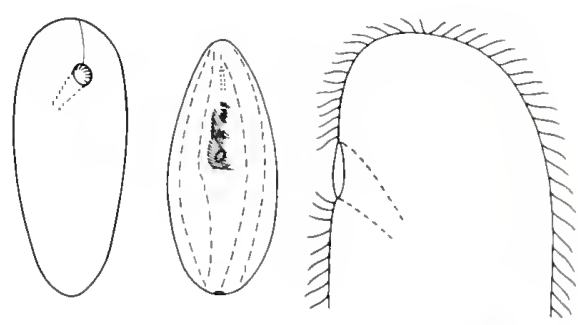

5 (4) Cytostome at base of ciliated apical vestibulum. Family COELOSOMIDIDAE.

5 (4) Cytostome on general cell surface or at base of nonciliated depression. 6

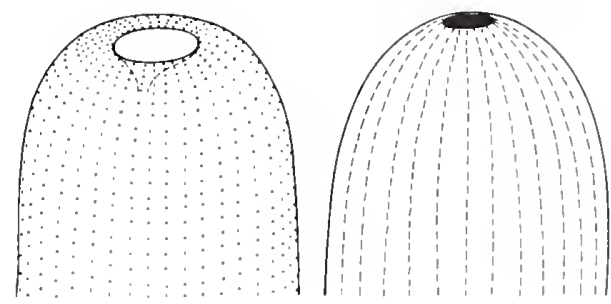


6 (5) Some ciliary rows terminating anteriorly against a neighiboring ciliary row. Posterior to the cytostome along this zone is a ribbon of $2-3$ closely set rows of short cilia. .............

6 (5) No such ribbon of short cilia present. ............... 8

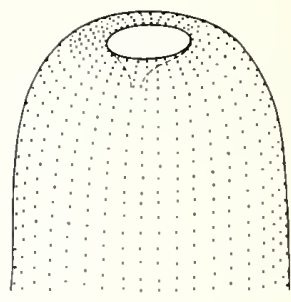

7 (6) Cytostome oval or circular, surrounded by cilia.

Family PRORODONTIDAE.

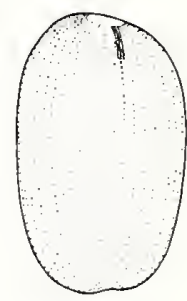

7 (6) Cytostome slitlike on a nonciliated ridge offset by a groove along which cilia are dense; anterior end obliquely truncate. Family SPATHIDIIDAE.

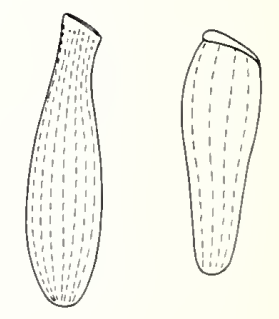

8 (6) Cell firm, noncontractile, barrel-shaped, with armored stavelike plates in cortex, usually with spines. Several cilia emerging between adjacent staves. Family COLEPIDAE.

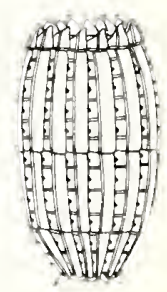

8 (6) Surface not as above. If firm, then only 1 cilium on each plate. . . . . . . . . 9 
9 (8) Clear vacuole filling posterior end of cell. Cilia closely set, apparently in whorls. Vase-shaped lorica present or absent. Surface firm, with rectangular alveoli. Family METACYSTIDAE.

9 (8) Clear vacuole not filling posterior end of cell. Never with lorica. . . . . . . . . . 10

10 (9) Ciliary rows spiraled when cell contracts. Macronucleus variously shaped with normal Feulgen reaction. Shapes various; behavior generally nonthigmotactic. Family ENCHELYIDAE.

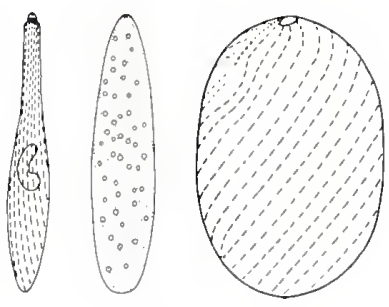

10 (9) No spiral contraction. Nuclei largely Feulgen negative. Animal generally highly thigmotactic, contractile, fragile, and snakelike in shape. Family TRACHELOCERCIDAE in part (also see couplet 95).

11 (4) Cytostome not in vestibulum. ................... 12

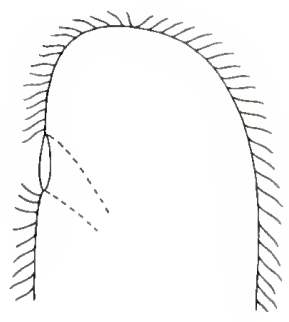

11 (4) Cytostome in vestibulum. ..................... 14

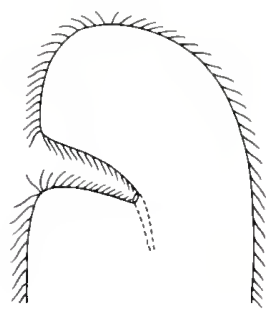


12 (11) Cilia in longitudinal rows. Free-living.

12 (11) Ciliary rows spiraled. Cytostome radially compartmented, rosetteshaped. Commensal in or on various invertebrates, especially arthropods. Family FOETTINGERIIDAE.

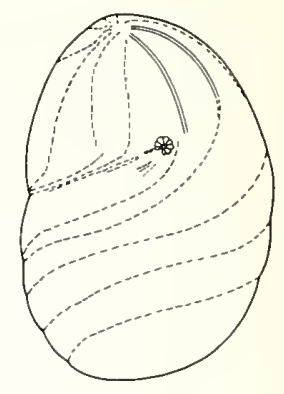

13 (12) Cytostome at base of proboscis. Three bipolar aboral closely set rows of short cilia. Family TRACHELIIDAE.

13 (12) Proboscis absent. Cytopharyngeal rods conspicuous. Triple dorsal rows of short cilia lacking. Family NASSULIDAE.

14 (11) Some ciliary rows terminating along edge of left half of vestibulum. ...................... 15

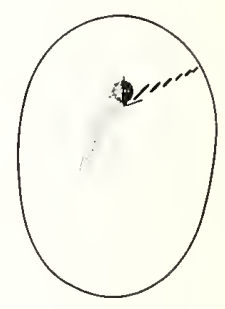

14 (11) Ciliary rows parallel to left edge of vestibulum and not terminating against its edge.
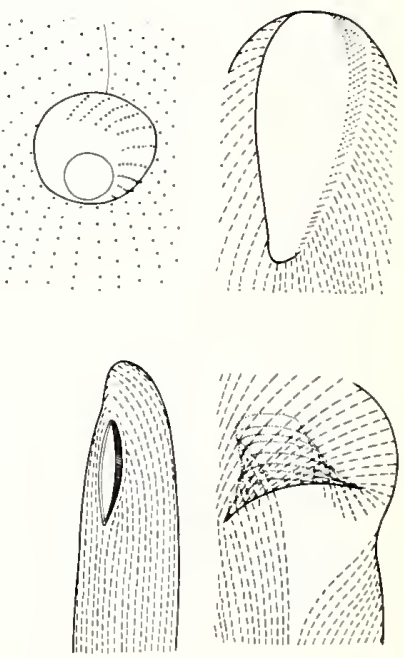
15 (14) Cell dorsoventrally flattened. Longitudinal nonciliated stripe extending from right corner of vestibulum at least one-half cell length ventrally. Vestibulum transverse. Family PLAGIOPYLIDAE.

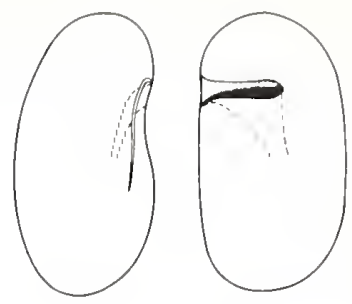

15 (14) Cell circular in cross section. Vestibulum oblique, triangular, or circular. No such unciliated stripe. ................... 16

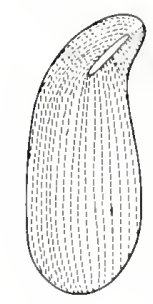

16 (15) Vestibulum triangular, anteroventral, all ciliary rows terminating against it. Living in various invertebrates. Family BALANTIDIIDAE.

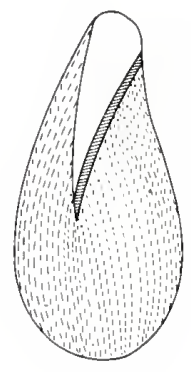

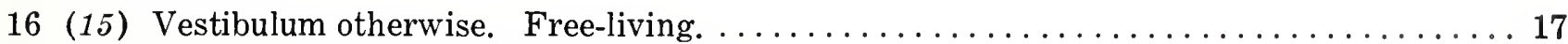

17 (16) Vestibulum circular; ciliary rows symmetrical. Cilia in left part of vestibulum in closely set radial rows independent of ciliary rows on general cell surface. Family CLATHROSTOMATIDAE.

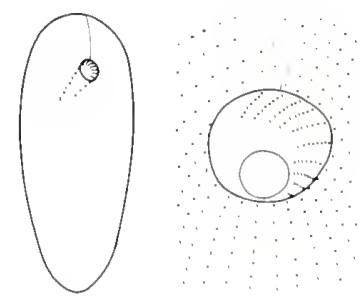

17 (16) Vestibulum generally narrow, oblique; ciliary rows asymmetrical. Cilia in left side of vestibulum apparently the modified anterior part of ciliary rows to left of vestibulum. Family COLPODIDAE.

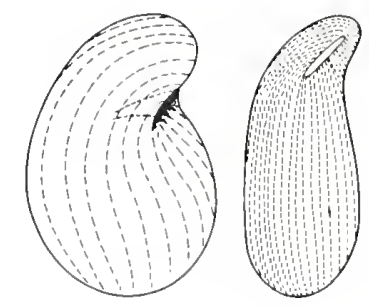


18 (14) Ciliary rows spiraled. Fingerlike projections near cytostome. Endocommensal in ctenophores. Pericaryon cesticola, order Trichostomatida (see Annotated Systematic List).

18 (14) Not as above.

19 (18) Vestibulum elongate; right edge of vestibulum with a narrow dense border of cilia. Closely set longitudinal rows of cilia along left edge of vestibulum. Macronucleus extensively Feulgen negative. Family GELEIIDAE.

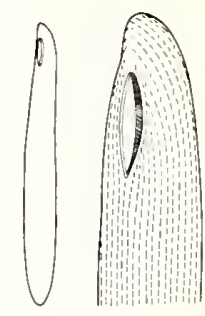

19 (18) Vestibulum and its cilia otherwise.

20 (19) Vestibulum longitudinal, narrow, about one-third to one-half body length, with one row of cilia. Endocommensal in sea urchins. Schizocaryum dogieli, Family PLAGIOPYLIDAE.

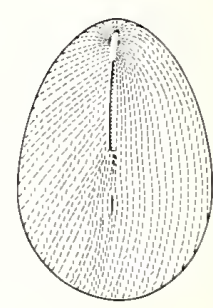

20 (19) Vestibulum otherwise.

21 (20) Vestibulum a pocket in posterior half of body.

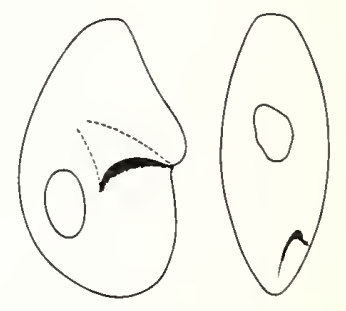

21 (20) Vestibulum in anterior half of body.

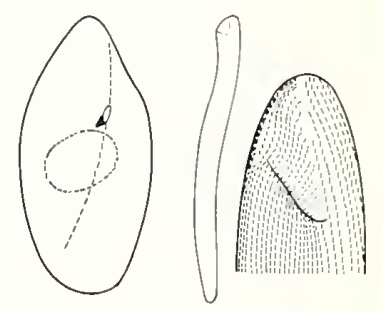


22 (21) Vestibular ciliary rows contiguous with somatic ciliary rows to right of cytostome. Endozoic in bivalves and snails. Family CONCHOPHTHIRIDAE (also see couplet 53).

22 (21) Vestibular ciliary rows contiguous with somatic ciliary rows to left of cytostome. Ectocommensal on gills of bivalve molluses. Family THIGMOPHRYIDAE (also see couplet 53).
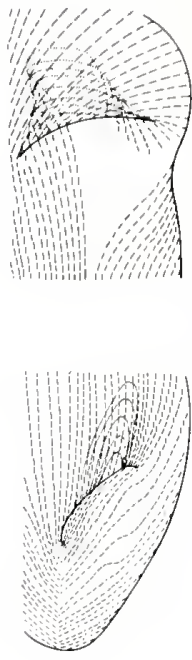

23 (21) Cell oval. Vestibulum one-third body length from anterior end and relatively small. Macronucleus oval. Endocommensal in bivalves. Gullmarella faurei, order Trichostomatida (see Annotated Systematic List).

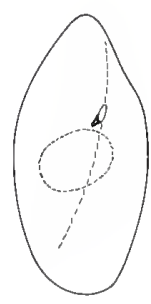

23 (21) Cell vermiform. Vestibulum large, triangular, near anterior end. Macronucleus elongate. Free-living. Conchostoma longissimum, order Trichostomatida (see Annotated Systematic List).

24 (3) Cell vermiform, attached by apex to renal epithelium of cephalopods. Family OPALINOPSIDAE.

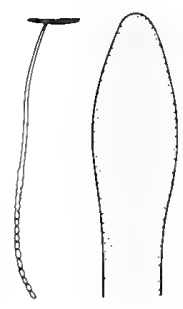


25 (24) Anterior end with holdfast apparatus of skeletal elements and areas of thigmotactic cilia.

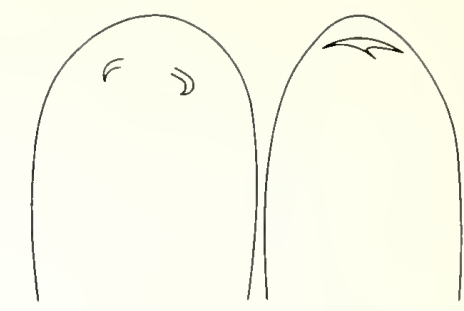

25 (24) Holdfast apparatus, if present, without skeletal elements.

26 (25) One or two hooks in holdfast apparatus under thigmotactic area. Cell about $21 \frac{2}{2}$ times longer than wide. Endocommensal in turbellarians.

Family HAPTOPHRYIDAE.

26 (25) No hooks in holdfast apparatus. Cell length more than $21 \frac{2}{2}$ times width. Endocommensal in gut of polychaetes. Family HOPLITOPHRYIDAE.
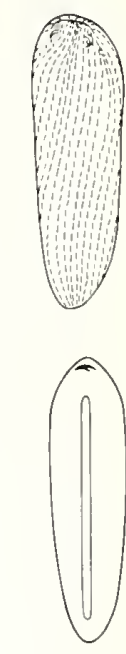

27 (25) Macronuclei scattered. Cell pyriform. Endozoic in polychaetes. Cyrtocaryum halosydnae, Family OPALINOPSIDAE.
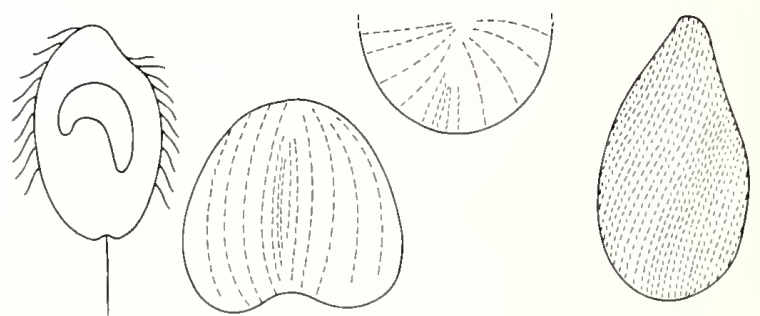

27 (25) Macronucleus single, central. Cell variously shaped.

28 (27) Anterior suctorial tentacle present, variously shaped. Ectocommensal on gills of bivalve molluscs. Macronucleus variably shaped. Family ANCISTROCOMIDAE in part (also see couplets 98 and 110).

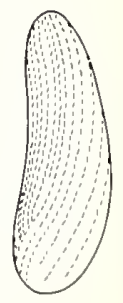


28 (27) No anterior suctorial tentacle present. Macronucleus long, axial. Endocommensal in gut of worms, particularly polychaetes. Family ANOPLOPHRYIDAE.

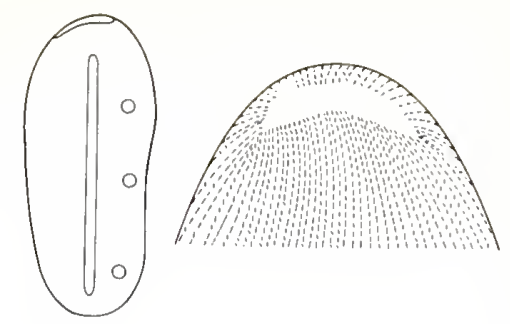

29 (2) A zone of 6 or more (commonly 25 to more than 100) membranelles anterior to and to the the left of the cytostome. 30

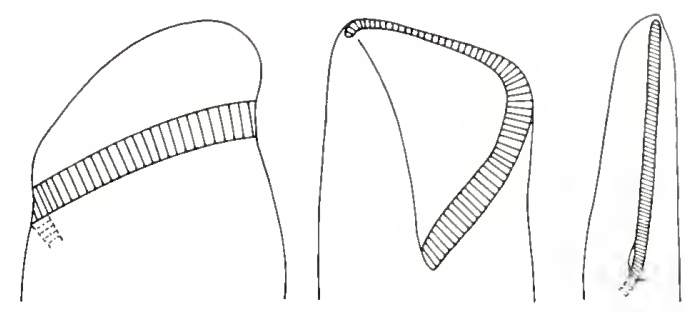

29 (2) Never more than 4 membranelles present. . . . 36

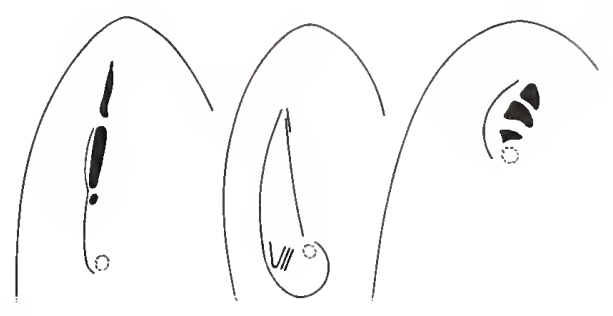

30 (29) Locomotory cilia organized in helical rows of cirri. Family SPIROFILIDAE (also see couplet 99 ).

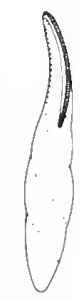

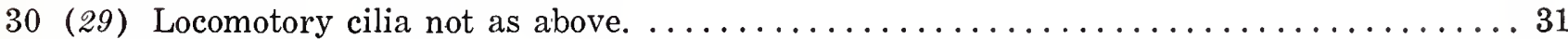

31 (30) Cell loricate, sessile. Family FOLLICULINIDAE.

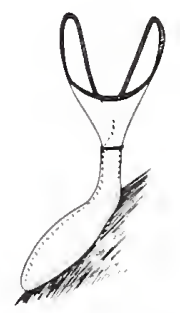

31 (30) Cell aloricate, generally free-swimming. 
32 (31) Conspicuous unciliated buccal cavity between zone of membranelles and large undulating membrane. ............... 33

32 (31) Essentially no unciliated surface between right border of zone of membranelles and adjacent ciliary rows. ................... 34

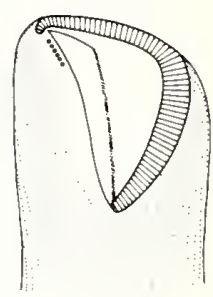

33 (32) Buccal cavity triangular. Macronucleus usually beaded. Family CONDYLOSTOMATIDAE.

33 (32) Buccal cavity circular. Macronucleus ribbonlike. Family CHATTONIDIIDAE.

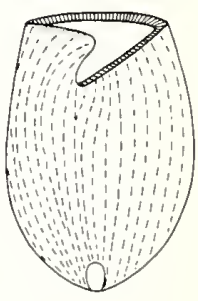

34 (32) Zone of membranelles apical, spiraled, enclosing ciliated field. Family STENTORIDAE.

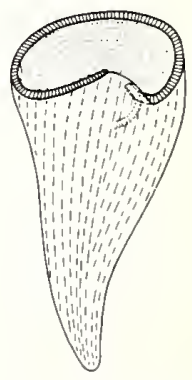

34 (32) Zone of membranelles longitudinal, or spiraled, and not apical. 
35 (34) Zone of membranelles longitudinal. Ciliary rows to right of zone of membranelles uniformly spaced. Family SPIROSTOMATIDAE.

35 (34) Zone of membranelles spiraling $90^{\circ}-180^{\circ}$ to the right, paralleled anteriorly by 4-5 closely set rows of cilia. Family METOPIDAE.

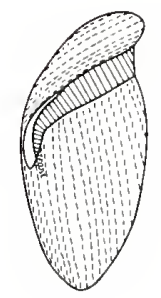

36 (29) Cytostome in anterior two-thirds of cell, usually in central one-third of body.

Free-living or endocommensal.

36 (29) Cytostome in posterior one-fifth of cell. Endocommensal in various invertebrates. . . 49

37 (36) One to three peniculi along left side of buccal cavity or winding across floor of buccal cavity. Undulating membrane inconspicuous. Cell densely ciliated, often over $150 \mu \mathrm{m}$ long, with sharply delimited buccal cavity. . . . 38

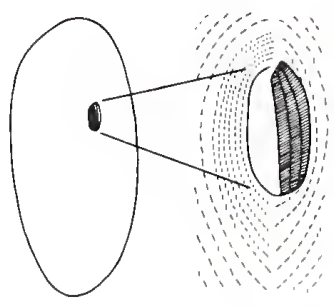

37 (36) No peniculi present. Undulating membrane present along right edge of buccal cavity. Remainder of buccal cilia variously arranged. Cell of various sizes. . . . . . . 40

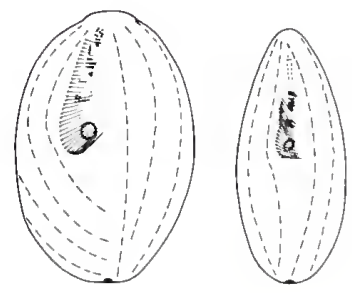


38 (37) Three peniculi winding across buccal cavity floor.

38 (37) One to three short longitudinal peniculi on left side of buccal cavity. Family FRONTONIIDAE.

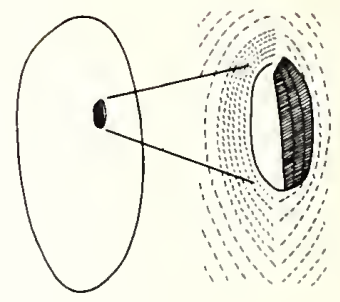

39 (38) Buccal cavity semispherical. Family OPHRYOGLENIDAE.

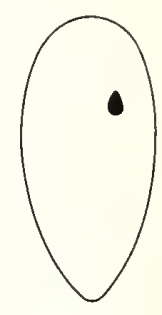

39 (38) Buccal cavity tubular, preceded by ciliated vestibulum. Family PARAMECIIDAE.

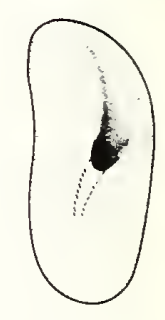

40 (37) Postbuccal ciliary rows present. Buccal cavity round to triangular, in anterior one-half of body. Undulating membrane Lshaped. Three buccal membranelles perpendicular to long axis of body.

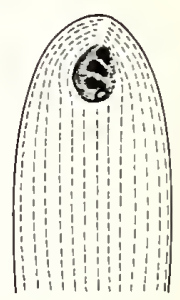

40 (37) No postbuccal ciliary rows. Buccal cavity elongate; cytostome often at or posterior to middle of body. Undulating membrane various. Other buccal cilia in various groups different from above.

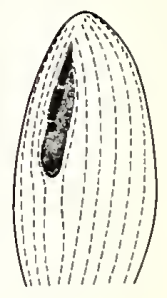


41 (40) Cilia to right of undulating membrane appear as transverse rows. Contractile vacuole midventral and central. Family LOXOCEPHALIDAE.

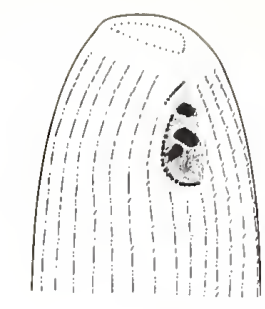

41 (40) No transverse rows apparent at level of buccal cavity. Contractile vacuole posterior. Family TETRAHYMENIDAE.

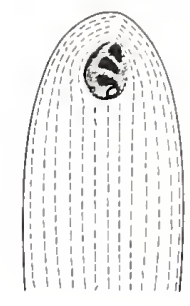

42 (40) Undulating membrane long, saillike. Other buccal cilia variously positioned but not immediately adjacent to undulating membrane. Family PLEURONEMATIDAE in part (also see couplet 52).

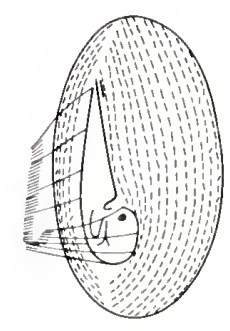

42 (40) Undulating membrane short, linear, or C-shaped, not extending beyond cytostome. Other buccal cilia closely adjacent to undulating membrane.

43 (42) Buccal cilia appearing as 2 dense parallel longitudinal series, neither more than 2 ciliary rows wide.
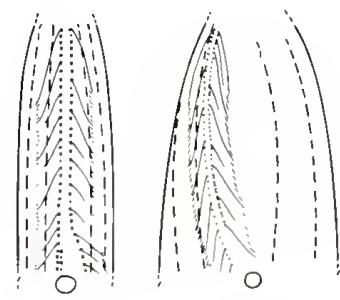

43 (42) Buccal cilia appearing as a single right-hand undulating membrane and 2 to several membranelles usually 2 cilia or more wide.

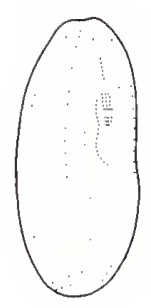


44 (43) Buccal cavity narrow; left-hand longitudinal series part of first ciliary row to left of cytostome. Family COHNILEMBIDAE.

44 (43) Buccal cavity wide. Left portion of buccal cilia a membrane 1-2 cilia wide, variously segmented into 1-3 linear parts, distinct from somatic ciliary rows. Family PSEUDOCOHNILEMBIDAE.

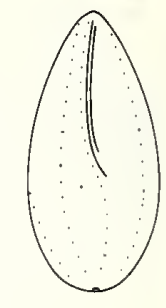

45 (43) Cell flat on one side with caudal projection. Endozoic in sea urchins. ........ 46

45 (43) Cell circular in cross section, without caudal projection. Including free-living and endocommensal forms.

46 (45) Anterior end truncate. Buccal cavity on small side, near anterior end, overhung by frontal lobe. Entorhipidium, Family ENTORHIPIDIIDAE.

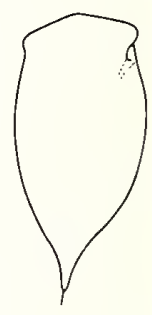

46 (45) Anterior end rounded. Buccal cavity variously located.

47 (46) Ciliary rows longitudinal, equidistant. Buccal cavity small in anterior onefourth of cell. Caudal projection small with 1 caudal cilium. Entodiscus, order Scuticociliatida (see Annotated Systematic List).

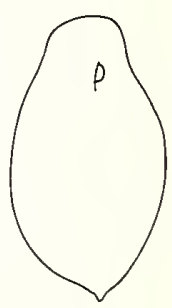

47 (46) Ciliary rows asymmetrical. Buccal cavity elongate, variously located. Caudal prolongation varying in size, with one to many cilia. Cryptochilum, Cryptochilidium, order Scuticociliatida (see Annotated Systematic List).

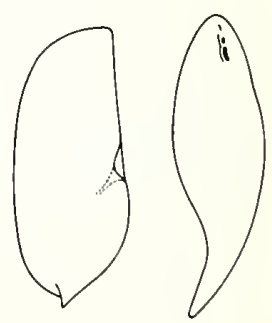


48 (45) Cell length variable, commonly over $70 \mu \mathrm{m}$. Anterior end tapered to blunt point. Right dorsolateral surface typically concave. Membranelles massive; cytostome anterior to equator. Family PHILASTERIDAE.

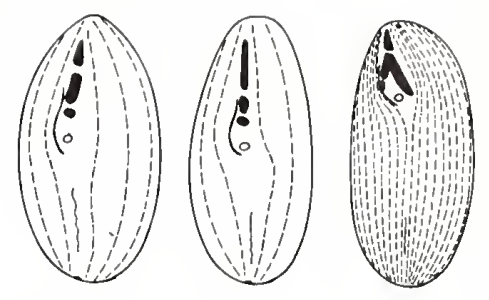

\begin{abstract}
ASTERIDAE.
\end{abstract}
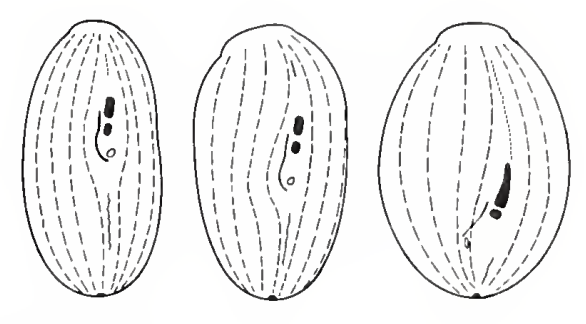

48 (45) Cell usually under $50 \mu \mathrm{m}$ in length. Anterior end truncated, conspicuously naked. Right dorsolateral surface typically convex. Membranelles inconspicuous. Cytostome often subequatorial. Family URONEMATIDAE.

49 (36) Anterior end with nonciliated V-shaped sucker. Endozoic in oligochaetes. Family HYSTEROCINETIDAE.

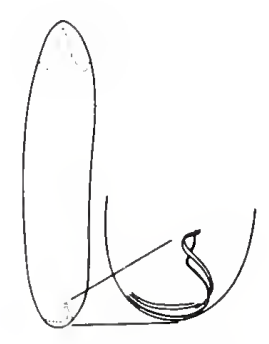

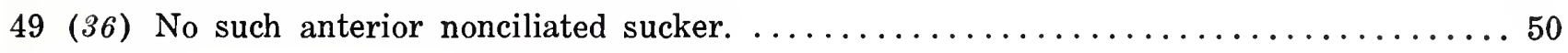

50 (49) Cell flattened, with distinct caudal projection. Endozoic in sea urchins. Biggaria (see Annotated Systematic List).

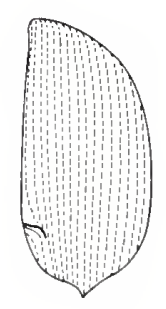

50 (49) Cell oval or circular in cross section. Posterior end rounded. ............51 
51 (50) Undulating membrane long, extending in a spiral along the periphery of the shallow buccal cavity. .......................... 52

51 (50) Undulating membrane short, linear, inconspicuous, in an oblique vestibulum near posterior end.

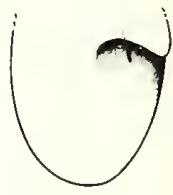

52 (51) Undulating membrane closely paralleled by ribbon of cilia, 2-3 cilia wide. Cytostome at or near posterior pole. On gills of bivalve molluscs or endozoic in echinoderms. Family HEMISPEIRIDAE in part (also see couplet 105).
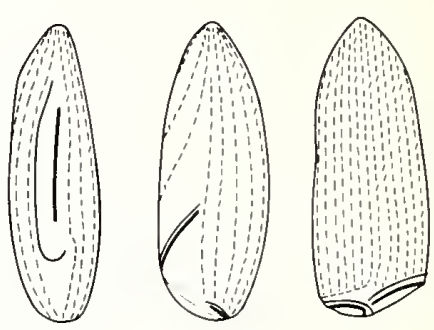

52 (51) Buccal cilia do not closely parallel undulating membrane; some arranged as transverse membranelles in forms of $\mathrm{V}$ or $\mathrm{Y}$ near cytostome. Commensal on hydroids and mussels. PLEURONEMATIDAE, in part, (Pleurocoptes, Peniculistoma) (also see couplet 42).
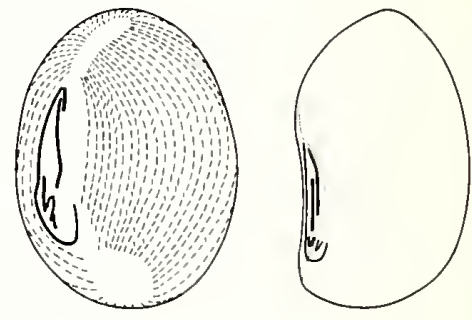

53 (51) Ciliary rows in vestibulum contiguous with somatic rows to right of cytostome. Endozoic in mussels. Family CONCHOPHTHIRIDAE (also see couplet 22).
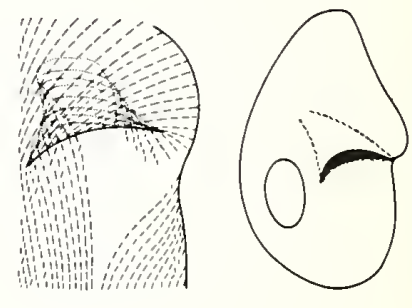

53 (51) Ciliary rows in vestibulum contiguous with somatic cilium rows to left of cytostome. On gills of bivalve molluscs. Family THIGMOPHRYIDAE (also see couplet 22).
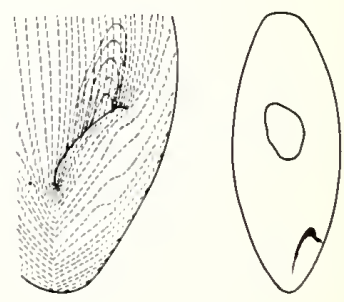
54 (1) Cilia mostly anterior or apical. Circlets of simple cilia sometimes occurring at the aboral pole or near the middle of the body. Cytostome present.
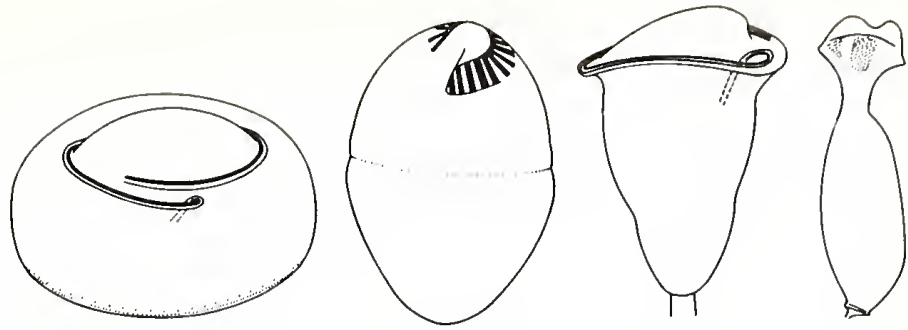

54 (1) Cilia restricted to one surface, or in circlets, parallel oblique rows, isolated groups of rows, or some other arrangement. Cytostome present or absent.

55 (54) Cell loricate. 56

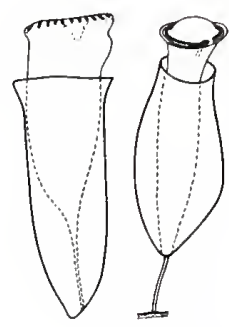

55 (54) Cell without lorica.

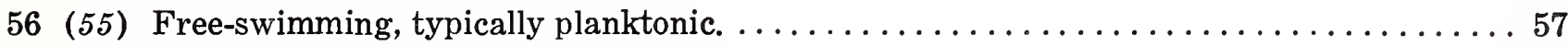

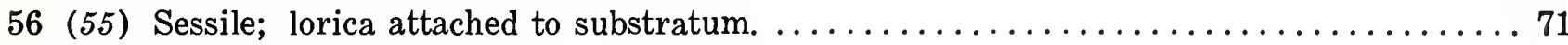

57 (56) Lorica with particles of foreign or self-constructed material on surface or within its layers. 58

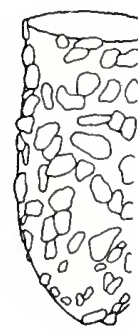

57 (56) Lorica without particles, but with a superficial reticulated pattern or polygonal network.

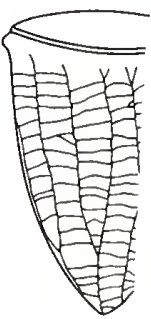

57 (56) Lorica clear; ringed, striated, or simple, but not granulated or reticulated.

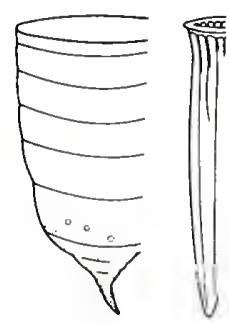


58 (57) Collar present, hyaline, with ring or spiral structure. Lorica topshaped; aboral end of lorica rounded to pointed; wall of bowl much thicker than that of collar. Family CODONELLOPSIDAE.

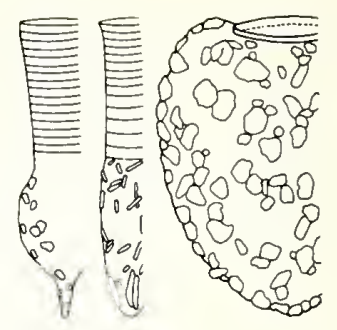

58 (57) Collar without ring or spiral structures, or absent.

59 (58) Lorica with small prisms and gelatinous mantle with scattered inclusions. Three longitudinal folds on posterior half of lorica. Collar present. Family TINTINNIDAE, in part (Brandtiella) (also see couplet 70).

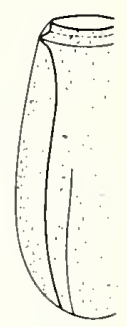

59 (58) Not as above. Lorica without longitudinal folds.

60 (59) Posterior narrowed horn or tail. No collar. Family COXLIELLIDAE, in part (Poroecus) (also see couplet 66).

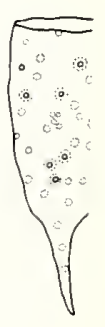

60 (59) Not as above. Lorica without tail.

61 (60) Lorica tubular and sacular, soft, gelatinous, thickly beset with particles. Lorica straight sided or flaring. Family TINTINNIDIIDAE.

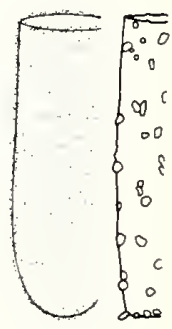


61 (60) Lorica firm, with or without collar. Aboral end may have a horn or be pointed. Family CODONELLIDAE.
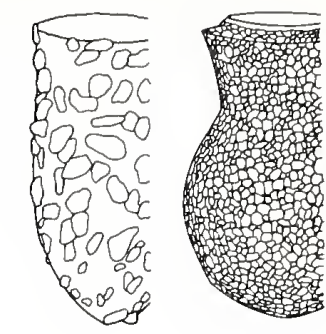

62 (57) Collar with 1 or 2 rows of holes. Lorica semispherical or oval. Family DICTYOCYSTIDAE.
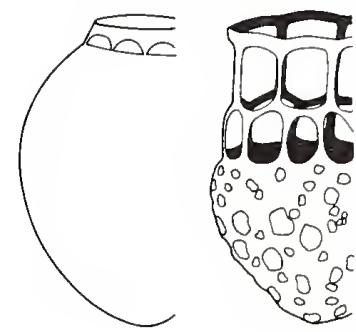

62 (57) Collar without holes. Lorica sometimes pointed posteriorly.

63

63 (62) Reticulum ending anteriorly in free, clearly differentiated lines.

Lorica acorn-shaped, with blunt, pointed or horned aboral end.

Wall thin and hyaline, deeply reticulated. Family EPIPLO-
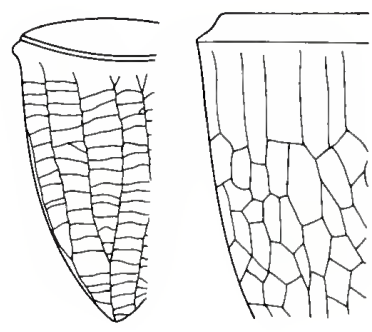

CYLIDIDAE.

63 (62) Anteriorly just as reticulated as rest of lorica............. 64

64 (63) Collar flared, set off by constriction. Oral edge slightly toothed or wavy. Lorica acorn-shaped, with posterior point. Family CYTTAROCYLIDIDAE.

64 (63) No flared collar. Oral edge with or without teeth. Lorica kettle-shaped or chalice-shaped. 
65 (64) One or two anterior suboral swellings. Lorica kettle-shaped; bowl elongate with suddenly pointed posterior. Family PTYCHOCYLIDIDAE, in part (Ptychocylis) (also see couplet 69).

65 (64) No anterior suboral swellings. Lorica elongate, chalice-shaped, with long, narrow aboral pedicle. Family XYSTONELLIDAE.

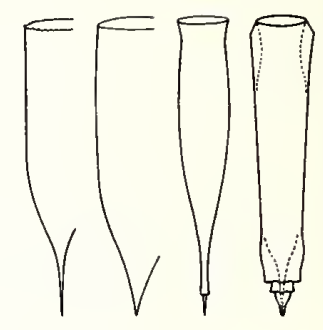

66 (57) A spiral band over at least oral one-half of lorica. Family COXLIELLIDAE in part (also see couplet 60 ).
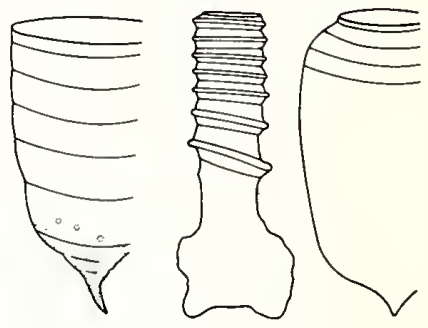

66 (57) Lorica simple, ribbed or ringed, but without spiral structures.

67 (66) Lorica short, cup- or goblet-shaped.

68

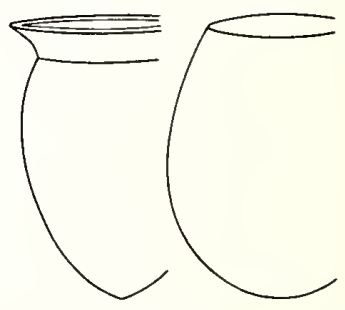

67 (66) Lorica long, bell- to trumpet-shaped. 69

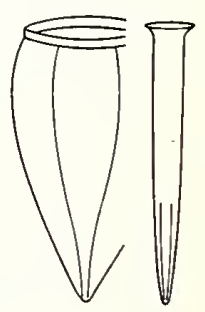


68 (67) Oral margin built into outer collar and inner shelf. Lorica clear. Family PETALOTRICHIDAE.

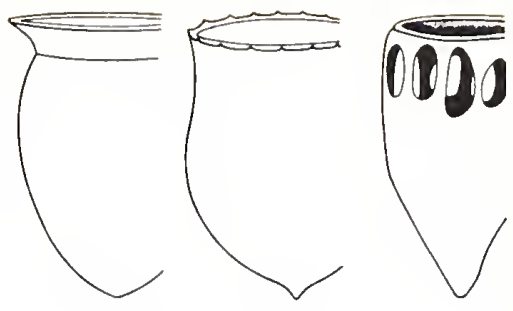

68 (67) Oral margin simple, without collar and shelf, and narrowed. Lorica simple or with rings. Family UNDELLIDAE.

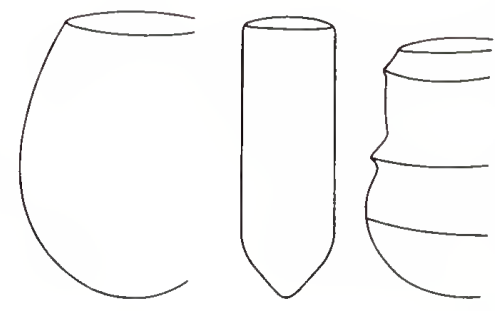

69 (67) Wall trilaminate. Oral margin not flared, and without ribs or striae. Lorica bell- or kettle-shaped; bowl typically cylindrical, elongate, with posterior point or horn. Family PTYCHOCYLIDIDAE, in part (Favella) (also see couplet $65)$.

69 (67) Wall simple, two layered. Oral margin flared. Ribs or striae often present. Lorica cup- to spindle-shaped.

70 (69) Oral aperture slightly flared, with broad, grooved rim. Longitudinal ribs or striae always present. Lorica cone- or chalice-shaped. Aboral end closed. Family RHABDONELLIDAE.

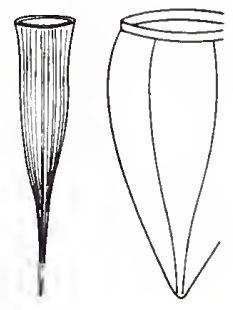

70 (69) Oral aperture flared, simple. Longitudinal ribs sometimes present. Lorica elongate, usually vase-shaped. Aboral end open or closed. Family TINTINNIDAE in part (also see couplet 59).

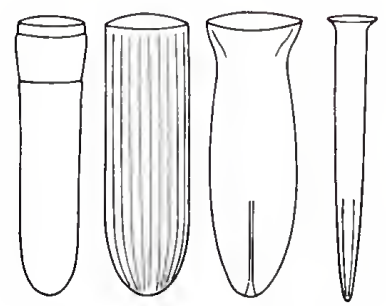


71 (56) Cell attached to lorica only at mouth aperture; only buccal cilia capable of being extended through opening of lorica. Stalk absent. Family LAGENOPHRYIDAE.

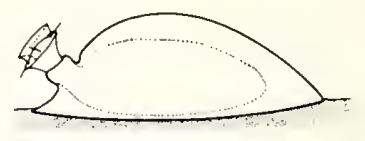

71 (56) Cell not attached to oral end of aperture; entire oral end of body extendable beyond opening of lorica. Stalk present, often short. Family VAGINICOLIDAE.

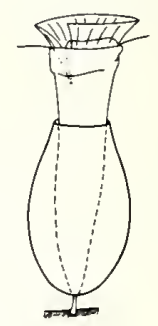

72 (55) Cell motile.

72 (55) Cell sessile.

73 (72) Aboral circlet(s) of cilia present. ........... 74

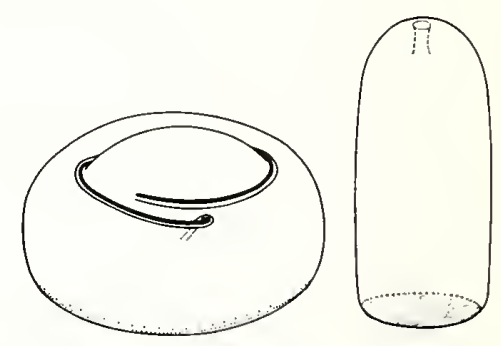

73 (72) No aboral circlet of cilia. Sometimes an equatorial circlet of cilia. . 76

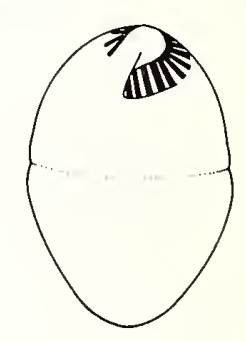

74 (73) Aboral adhesive disc strengthened by skeletal ring. Family URCEOLARIIDAE.

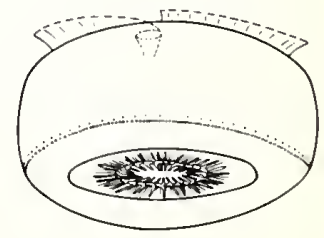


74 (73) No aboral adhesive disc. Migratory motile stages of ciliates of order Peritrichida, suborder Sessilina.

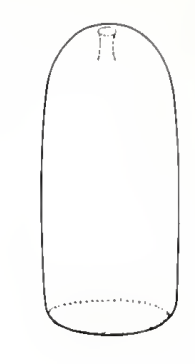

75 (74) Skeletal ring with 20-50 smooth links. Subfamily Urceolarinae.

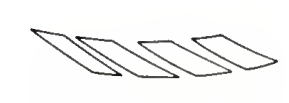

75 (74) Skeletal ring of hooked or spiked links. Subfamily Trichodininae.

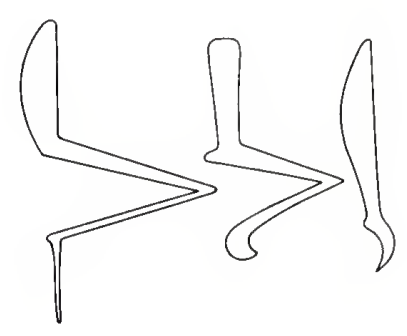

76 (73) Cytostome on ventral surface, not surrounded by zone of membranelles. Family HALTERIIDAE.

76 (73) Cytostome apical, enclosed within spiral zone of membranelles. Family STROBILIDIIDAE.
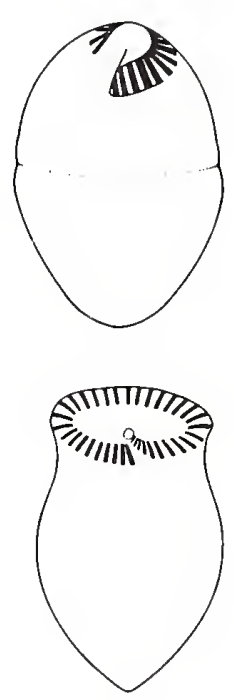

77 (72) Zone of membranelles winding at least $360^{\circ}$ to anteroventral cytostome. Family LICNOPHORIDAE.

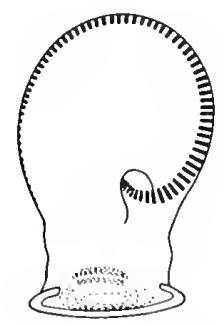

77 (72) Buccal cilia not in a clockwise zone of membranelles. 
78 (77) Buccal cilia in apical counterclockwise groups that descend helically down a deep, tubular buccal cavity. Animal cup- or bell-shaped, solitary or colonial.

78 (77) Buccal cilia inconspicuous, in groups within apical cone or funnel.

Animal cylindrical or spindle-shaped, with flaring apex, noncolonial. . . . 81

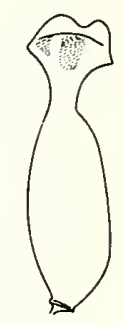

79 (78) A differentiated stalk present.

79 (78) Stalk absent. Family SCYPHIDIIDAE.

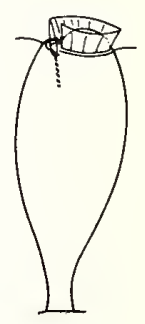

80 (79) Stalk contractile. Family VORTICELLIDAE.

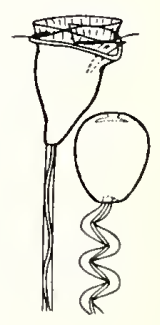

80 (79) Stalk not contractile. Family EPISTYLIDIDAE. 
81 (78) Stalk at least as long as body. Family CHILODOCHONIDAE.

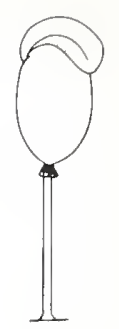

81 (78) Stalk less than one-fourth length of body or absent. $\ldots \ldots \ldots \ldots \ldots \ldots \ldots \ldots \ldots$

82 (81) Apical funnel in 3 spirals. Family SPIROCHONIDAE.

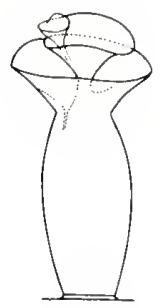

82 (81) Apical funnel single or double, and not spiraled. Family STYLOCHONIDAE.

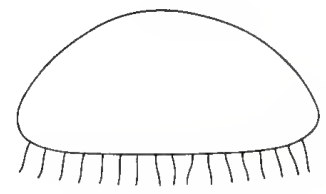

83 (54) Cilia restricted to ventral surface. Dorsal surface nonciliated, with cilia only at borders, or with sparse rows or groups of cilia not used in locomotion. (These diagrams show cross sections of animals).

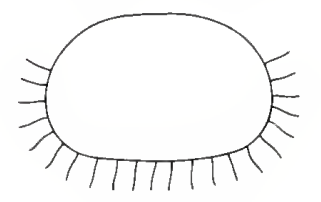

83 (54) Cilia not restricted to one surface, in cir. clets, parallel oblique rows, isolated groups of rows, or some other arrangement. 104

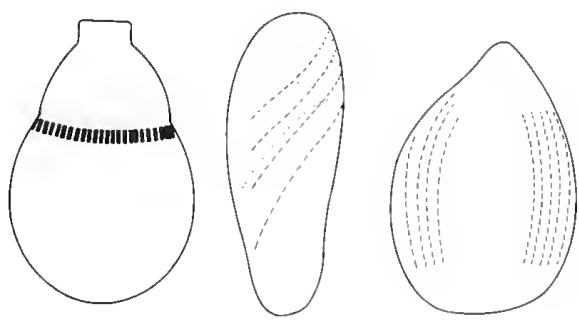


84 (83) Locomotory cilia simple, in rows.

84 (83) Locomotory cilia organized as cirri in rows/or groups.

85 (84) Cytostome ventral. Body seldom twice as long as wide.

85 (84) Cytostome anterior, lateral on narrow edge, or absent. Body of various shapes.
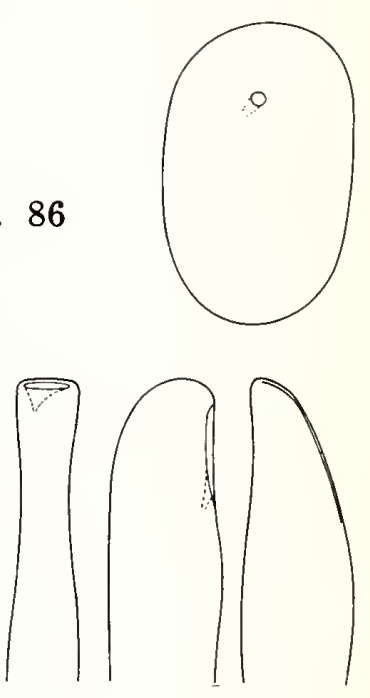

$86(85)$ Cytopharyngeal rods present. $\ldots \ldots \ldots \ldots \ldots \ldots \ldots \ldots \ldots \ldots$

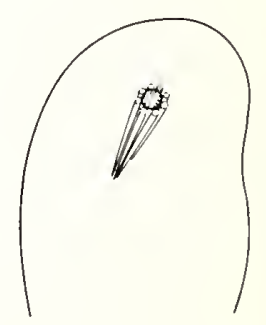

86 (85) Cytopharyngeal rods absent. 
87 (86) Posteroventral stylus or secretory organelle of attachment present. Usually 2 cytopharyngeal rods. Family DYSTERIIDAE.

87 (86) No such stylus present. Cytopharyngeal rods in conical group. Family CHLAMYDODONTIDAE.

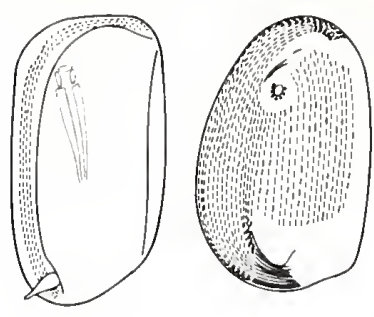

88 (86) Zone of membranelles present. 89
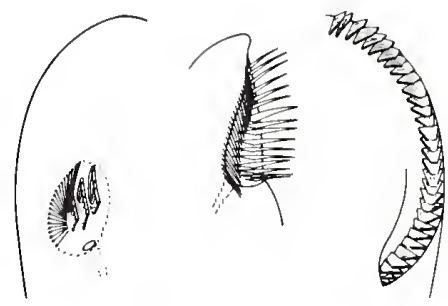

88 (86) Zone of membranelles absent

89 (88) Cell firm, grooved, buccal cavity midventral, with 3 membranelles. Family CINETOCHILIDAE.

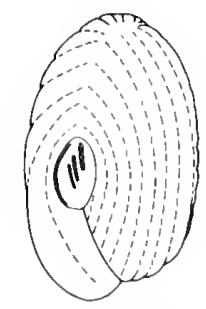

89 (88) Cell soft, flexible, buccal cavity otherwise. 
90 (89) Zone of membranelles bordering anterior end. Length over $70 \mu \mathrm{m}$. Family PERITROMIDAE.

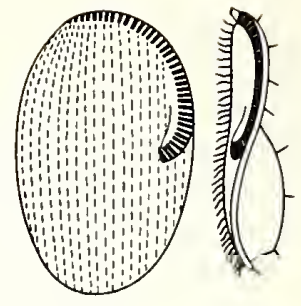

90 (89) Zone of membranelles reduced, limited to buccal cavity. Length under $70 \mu \mathrm{m}$. Protocruzia, order Heterotrichida (see Annotated Systematic List).

91 (88) Cilia ventral in dense curving band. Motile larval stages in life cycle of members of the order Chonotrichida.

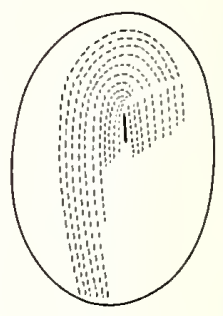

91 (88) Cilia in C-shaped rows along borders of cell. Askoella, Conidiophrys (tomite only), and Phthorophyra. Family ASKOELLIDAE (also see couplet 112).
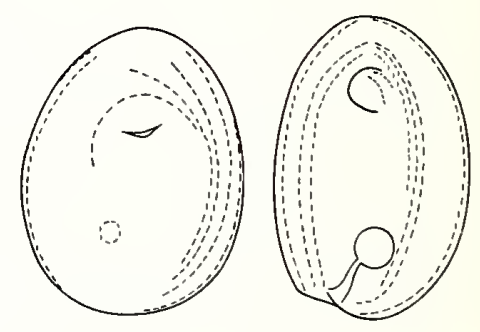

2 (85) Cytostome apical or lateral often inconspicuous. 93

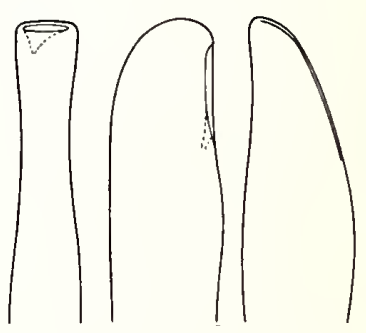

92 (85) Cytostome absent.

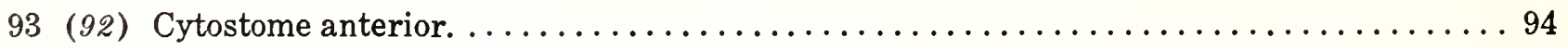

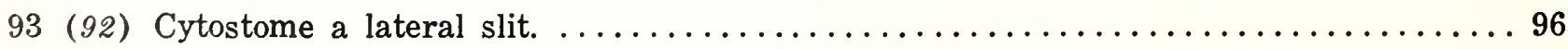


94 (93) At least some of cilia in bipolar rows. Macronuclei small, vesicular. . . . . . . . . 95

94 (93) Ciliary rows in a ventral band about one-half cell width, extending about four-fifths cell length. Macronucleus single, large, C-shaped. Family CRATERISTOMATIDAE.

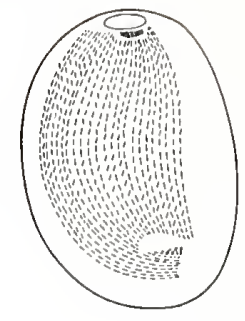

95 (94) Body contractile and snakelike in shape. Cytostome circular. Family TRACHELOCERCIDAE, in part (also see couplet 10).

95 (94) Cell length less than $50 \mu \mathrm{m}$, humped dorsally. Cytostome anterior and slitlike. Family STEPHANOPOGONIDAE.
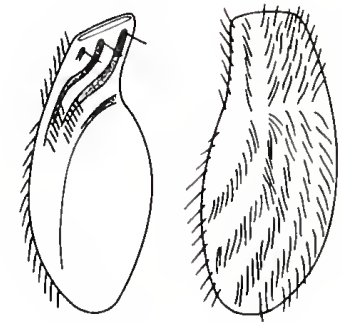

96 (93) Cytostome on concave left edge of body, preceded by hooklike lateral extension. Nuclei vesicular. No contractile vacuole. Family LOXODIDAE.

96 (93) Cytostome on convex left edge. Macronuclei one to several, not vesicular. One to several contractile vacuoles. Family AMPHILEPTIDAE. 
97 (92) Anterior suctorial tentacle or sucking disc present. . 98

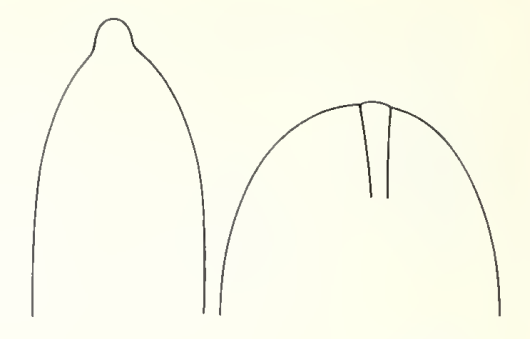

97 (92) No anterior suctorial tentacle Silenella ovoidea, order Suctorida (see Annotated Systematic List).

98 (97) Cilia restricted to one flattened surface. A short (about 8 cilia) ciliary row at anterolateral margin. Commensal on hydroids, and in branchial cavity of ascidians. Family HYPOCOMIDAE.

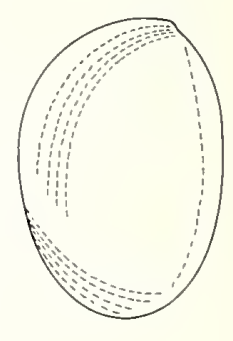

98 (97) Cell ovoid to pyriform in shape. No such short ciliary row, or ciliary rows more extensive. Ectocommensal on gills of bivalve molluscs. Family ANCISTROCOMIDAE (also see couplets 28 and 110).

99 (84) Helical torsion reduces aboral surface. Ventral cirri in helical rows. Family SPIROFILIDAE (also see couplet 30 ).

99 (84) Aboral surface not so reduced, usually bearing sparse, widely spaced rows of simple (often very short) cilia not used in locomotion. ............. 100

100 (99) Cirri of midventral axis arranged in a closely set double row-actually a single zigzag series. Family HOLOSTICHIDAE. 
100 (99) Cirri of midventral axis in single rows or isolated groups, but not in a zigzag series.

101 (100) Practically all cirri arranged in parallel rows. . . . . . . . . . . . . . 102

101 (100) Cirri of midventral surface arranged in groups. Marginal cirrus rows sometimes present. ................................ 103

102 (101) Cell oval, with large buccal cavity. Rows of cirri curved, paralleling edges of buccal cavity. Undulating membrane well developed. Family PSILOTRICHIDAE.

102 (101) Cell more elongate, cirri in parallel rows that extend well beyond the buccal cavity. Family UROSTYLIDAE.

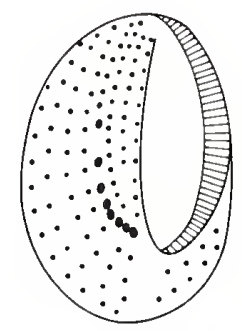

103 (101) At least 2 rows of cirri present, each with more than 5 (usually 20 or more) cirri in addition to groups of cirri. Family OXYTRICHIDAE.

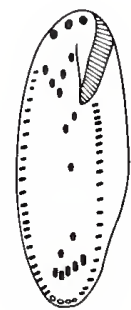

103 (101) No such marginal rows present, or at least 1 row reduced to fewer than 5 cirri; remaining ventral cirri in groups. Family EUPLOTIDAE.

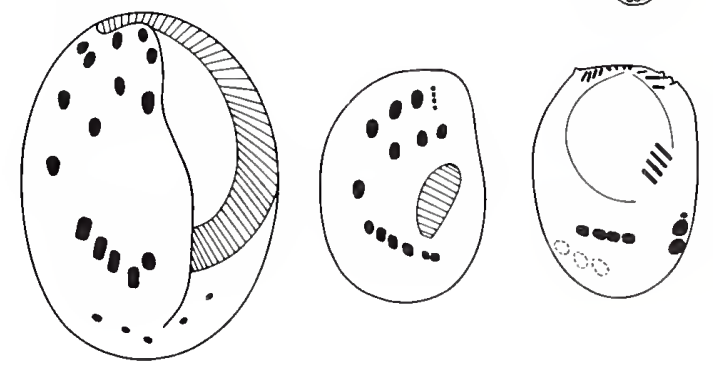


104 (83) Cytostome apical. Cilia in circlets or spiraling whorls. .......................... 105

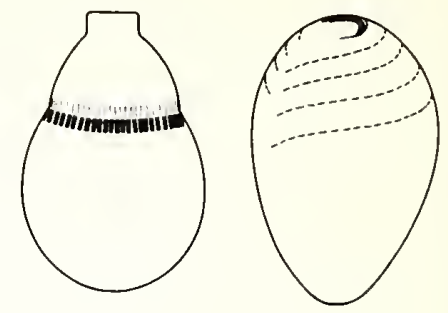

10.4 (83) Cytostome nonapical or absent. Cilia in parallel oblique rows, isolated groups of rows or some other arrangement. ..... 106

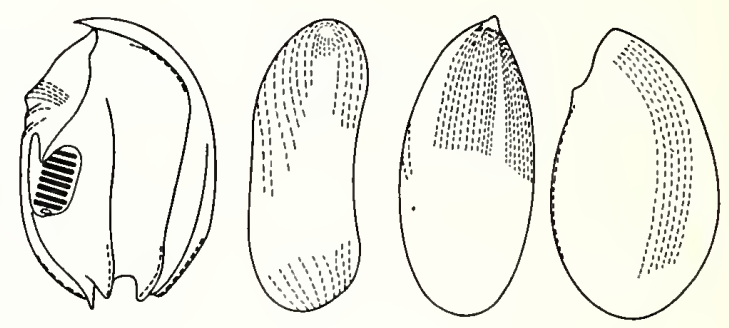

105 (104) Cytostome on cell surface, often on a conical prominence. Retractile seizing organelles in some species. Cilia in circlets. Family DIDINIIDAE.

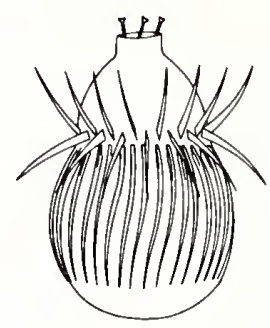

105 (104) Cytostome in apical vestibulum. Cilia in spiraling whorls. Family TRIMYEMIDAE.

105 (104) Cytostome at posterior pole. Prominent spiraling undulating membrane present. Anterior group of thigmotactic cilia present. Ectocommensal on gills of bivalve molluses. Family HEMISPEIRIDAE, in part (also see couplet 52).

106 (104) Cell laterally compressed, with rigid pellicle. Cytostome and compound cilia prese"t.

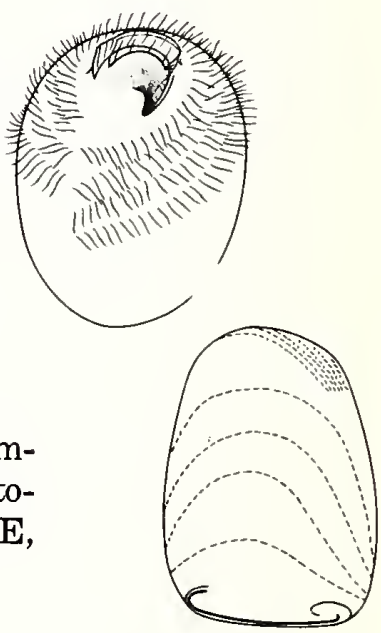

106 (104) Cell without rigid pellicle or cytostome. All cilia simple. 109 
107 (106) Zone of membranelles in spiraling buccal cavity, paralleled anteriorly by 5 closely set rows of cilia. One to three posterior spines present. Family CAENOMORPHIDAE.

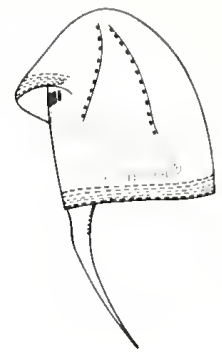

107 (106) A rectangular group of 9-12 membranelles in small buccal cavity. Seven rows of prebuccal cilia. No posterior spines present.

108 (107) All somatic cilia simple. Family EPALXELLIDAE.

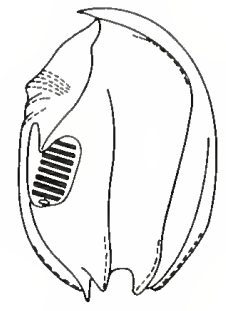

108 (107) One to two posterior cirri present. Family MYLESTOMATIDAE.

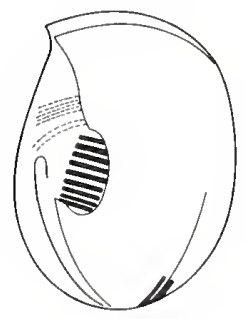

109 (106) Apical suctorial tentacle or sucking disc present. Ciliary rows straight or spiraled, usually only one-third to two-thirds cell length, terminating near suctorial tentacle. Ectocommensal on

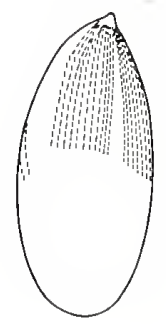
gills of bivalve mollusc.

109 (106) No suctorial tentacle or sucking disc. Cilia in 1-3 fields, including a ribbon of 4-15 parallel oblique ciliary rows encircling cell like a neck scarf. Ciliated larvae, order Suctorida. (Families separated by adult morphology, couplets 112-121.)
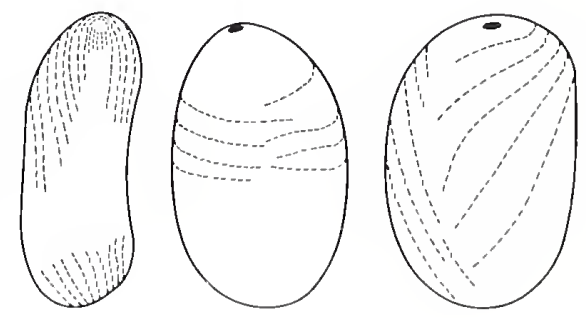
110 (109) Ciliary rows equidistant, usually about two-thirds cell length. Family ANCISTROCOMIDAE (also see couplets 28 and 98).

110 (109) Ciliary rows in 2 longitudinal groups of 4-6 short ciliary rows each. . 111

111 (110) Cell pyriform. Tomite of member of family SPHENOPHRYIDAE (also see couplet 113).

111 (110) Cell laterally compressed. Ridge separating the 2 ciliated surfaces. Family SPHENOPHRYIDAE (Lwoffia cilifera).
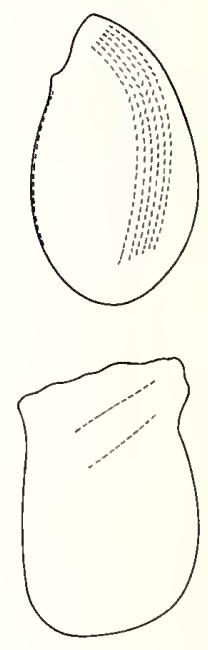

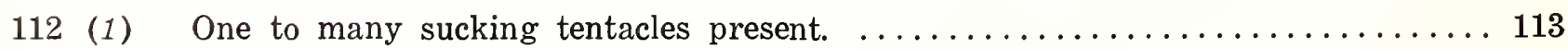

112 (1) No sucking tentacles present. Attached to exoskeletal hairs of crustaceans. Family ASKOELLIDAE (Conidiophrys) (also see couplet 91).

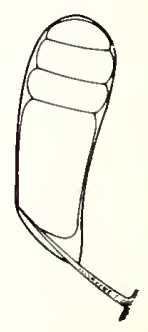


113 (112) One short sucker present. Attached to gills of bivalve molluscs in part by large, flat sole. Family SPHENOPHRYIDAE (also see couplet 111).

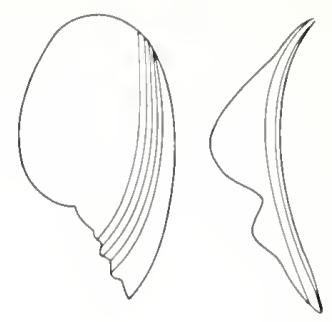

113 (112) Several tentacles present. In various habitats.

114 (113) Cell with lorica.

114 (113) Cell without lorica.

115 (114) Tentacles of two definite types. Family EPHELOTIDAE, in part (Actinocyathus, Podocyathus) (also see couplet 118).

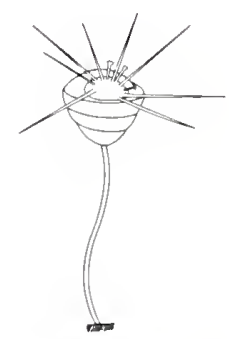

115 (114) Tentacles all similar.

116 (115) Tentacles with enlarged tips, in clusters. Family ACINETIDAE.

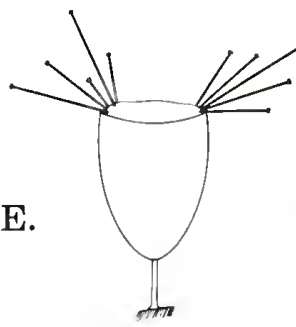

116 (115) Tentacles not clustered. Family PODOPHRYIDAE, in part (Paracineta, Metacineta) (also see couplet 120). 
117 (114) Stalk present by which cell is attached to substratum. 118

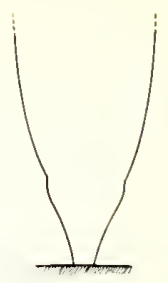

117 (114) Stalk absent. Cell attached to substratum by broad flattened surface.

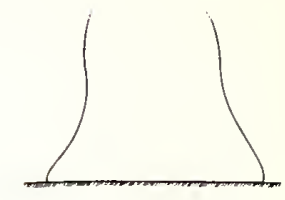

118 (117) Tentacles of two definite types. Family EPHELOTIDAE (also see couplet 115).

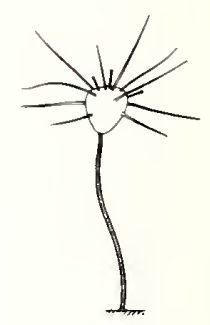

118 (117) Tentacles all similar.

119 (118) Cell beyond stalk elongate, at least twice as long as broad. Stalk usually short. Family OPHRYODENDRIDAE.

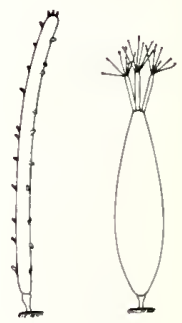

119 (118) Cell beyond stalk less than twice as long as broad, often globular. Stalk often as long as rest of cell.

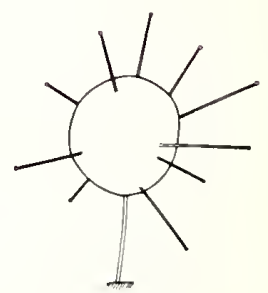


120 (119) Bud developing within cavity of parental suctorian. Family DISCOPHRYIDAE.

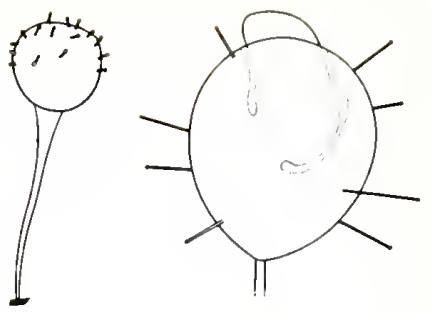

120 (119) Bud developing externally on parental suctorian. Family PODOPHRYIDAE (also see couplet 116).
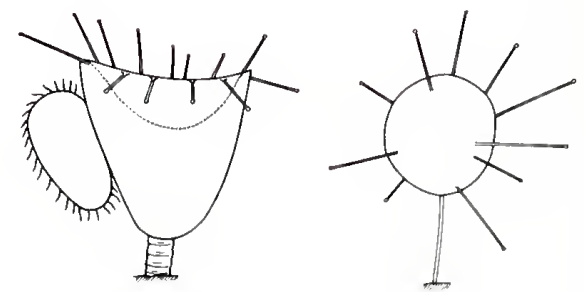

121 (117) Tentacles minute, on surface next to substratum, acting only as organelles of attachment. On appendages of polychaetes. Family PHALACROCLEPTIDAE.

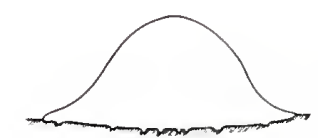

121 (117) Tentacles used in feeding, and in clusters on superior surface.

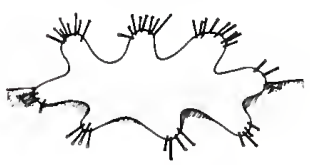
Family DENDROSOMATIDAE.

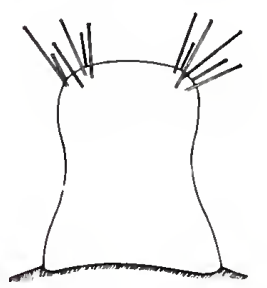




\section{ANNOTATED SYSTEMATIC LIST}

The following list is arranged according to the classification used in The Ciliated Protozoa (Corliss, 1961), with modifications based on more recent revisions. No ranges are given since most species are cosmopolitan, their distributions depending more on microhabitat than on macrodistributional factors. Notes on systematics and ecology are given when they are important in identification of the taxa. Important papers on a given family are also mentioned (see Selected Bibliography).

\section{Class Ciliata}

\section{Order Gymnostomatida}

Family AMPHILEPTIDAE Bütschli, 1889. Four genera with marine representatives: $A m$ phileptus, Hemiophrys, Litonotus, and Loxophyllum; all free-living and benthic. See Kahl (1931) and Canella (1960).

Family CHLAMYDODONTIDAE Stein, 1859. At least eight genera with marine representatives: Atopochilodon, Chilodonatella, Chilodonella, Chlamydodon, Chlamydonella, Lynchella, Odontochlamys, and Parachilodonella. Free-living and benthic. See Dobrzanska-Kaczanowska (1963), Dragesco $(1966,1967)$, and Deroux (1970).

Family COLEPIDAE Ehrenberg, 1838. Freeliving, widespread. Two genera: Coleps and Tiarina; both marine. See Kahl (1930).

Family DIDINIIDAE Poche, 1913. Ten genera described, mostly marine: Acropisthium, Askenasia, Choanostoma, Ctenoctophrys, Cyclotrichium, Didinium, Liliimorpha, Mesodinium, Monodinium, and Zonotrichium. Mesodinium widespread and ubiquitous; planktonic, but also occurs near substrata. See Kahl (1930).

Family DYSTERIIDAE Claparède and Lachmann, 1858. Free-living and benthic, or ectocommensal on crustaceans and fish. At least eight genera with marine representatives: Brooklynella, Dysteria, Hartmannula, Mirodysteria, Paratrochilia, Sigmocineta, Trochilia, and Trochilioides. See Jankowski (1967a).
Family ENCHELYIDAE Ehrenberg, 1838. Free-living, widespread. This is a large, loosely defined family in need of serious systematic revision. Genera with marine species: Chaenea, Chilophrya, Enchelyodon, Enchelys, Helicoprorodon, Holophrya, Ileonema, Lacrymaria, Lagynurus, Longitricha, Microregma, Nannophrya, Pithothorax, Placus, Plagiocampa, Platyophrya, Rhopalophrya, and Spasmostoma. See FauréFremiet (1961c).

Family LOXODIDAE Bütschli, 1889. Four genera with marine representatives: Ciliofaurea, Kentrophoros, Loxodes, and Remanella; all free-living, benthic, usually among sand grains. Kentrophoros is a ribbonlike psammolittoral ciliate usually included in this family, but it is of uncertain affinities since its cytostome has yet to be described. Cryptopharynx, usually placed in the family CHLAMYDODONTIDAE also keys out here. See Dragesco (1960).

Family METACYSTIDAE Kahl, 1926. Three genera: Metacystis, Pelatractus, and Vasicola. Metacystis occurs regularly in tidal marshes. See Kahl (1930).

Family NASSULIDAE de Fromentel, 1874. Five genera with marine species: Chilodontopsis, Nassula, Nassulopsis, Orthodonella, and Stomatophrya. Free-living. See Agamaliev (1967) and Dragesco (1960).

Family PRORODONTIDAE Fauré-Fremiet, 1961. This family, split from the family ENCHELYIDAE by Fauré-Fremiet in 1961 (1961c), contains at least the following genera, all with marine species: Lagynophrya, Prorodon, Trachelophyllum, and Urotricha. Freeliving, widespread.

Family SPATHIDIIDAE Kahl in Doflein and Reichenow, 1929. At least ten genera (listed in Corliss, 1961). Free-living and benthic. See Kahl (1930).

Family STEPHANOPOGONIDAE Corliss, 1961. One genus, Stephanopogon, free-living in marine sands and algal mats. See Dragesco (1963b) and Borror (1965b).

Family TRACHELIIDAE Ehrenberg, 1838. At least three marine genera: Dileptus, Paradileptus, and Trachelius; all free-living. See Dragesco (1963a). 
Family TRACHELOCERCIDAE Kent, 1880. Six genera: Gruvelina, Nephrocerca, Protrichophora, Trachelocerca, Trachelonema, and Tracheloraphis; all free-living, marine, and characteristic of sandy substrata. See Dragesco (1960).

\section{Order Trichostomatida}

Family BALANTIDIIDAE Reichenow, 1929. One genus, Balantidium; free-living and in the gut of polychaetes and amphipods and the gastrovascular cavity of medusae. See Kahl (1934a) and Fauré-Fremiet (1955).

Family CLATHROSTOMATIDAE Kahl, 1926. This family (also known as PARANASSULIDAE Fauré-Fremiet, 1961) is placed here rather than in the Gymnostomatida as the vestibular ciliature used in feeding is distinct from the somatic cilia. As some of these ciliates may possess structures interpretable as peniculi, their inclusion in the Trichostomatida is artificial. One genus with marine species, Paranassula. Free-living. See Fauré-Fremiet (1962a). Gullmarella faurei Fenchel, 1964, endocommensal in bivalves, is of uncertain position in this order since little is understood of its morphogenesis, but may also belong in this family. See Fenchel (1964).

Family COELOSOMIDIDAE Corliss, 1961. Three genera with marine representatives: Coelosomides, Paraspathidium, and Pseudoprorodon; free-living. Conchostoma longissimum Fauré-Fremiet, 1963, is a species of uncertain taxonomic position in this order, but may belong in this family.

Family COLPODIDAE Ehrenberg, 1838. Contains Woodruffia (in estuaries) and Colpoda (typically a soil ciliate, but sometimes found in tidal marshes). Free-living. See Kahl (1931) and Prelle (1963).

Family GELEIIDAE Kahl, 1933. Two genera: Corlissia and Geleia; free-living in marine sands and algal mats. The genus Corlissia is of questionable systematic position, since little is understood of the cilia in the region of the cytostome. See Dragesco (1960).

Family PLAGIOPYLIDAE Schewiakoff, 1896. At least four genera with marine species: Lech- riopyla, Plagiopyla, Plagiopyliella, and Sonderia. Free-living or endocommensal in sea urchins. See Kahl (1933). Schizocaryum dogieli Poljansky and Golikova, 1957, endocommensal in sea urchins, may also be a member of the family PLAGIOPYLIDAE. See Berger (1961d).

Family TRIMYEMIDAE Kahl, 1933. One genus, Trimyema. Free-living. See review by Fauré-Fremiet (1962b).

Pericaryon cesticola Chatton, 1911 was described as endocommensal in the ctenophore, Venus' girdle, Cestus veneris. This species has been regarded as being in the family FOETTINGERIIDAE (order Apostomatida), but possesses a vestibulum and lacks a cytostomal rosette. See Chatton and Lwoff (1935).

\section{Order Chonotrichida}

Family CHILODOCHONIDAE Wallengren, 1895. One genus, Chilodochona; ectocommensal on the exoskeleton of Ebalia and Portunus. See Fauré-Fremiet, Rouiller, and Gauchery (1956).

Family SPIROCHONIDAE Stein, 1854. One genus, Spirochona; ectocommensal on pleopodal bristles of gammaridean amphipods. See Matsudo and Mohr (1968).

Family STYLOCHONIDAE Mohr, 1948. Five genera with marine species: Heliochona, Kentrochona, Lobochona, Oenophorachona, and Stylochona; ectocommensal on crustaceans (including Nebalia and Limnoria). See Matsudo and Mohr (1965) and Mohr, Levague, and Matsudo (1963).

\section{Order Suctorida}

Family ACINETIDAE Stein, 1859. At least eight genera with marine species: Acineta. Acinetopsis, Dactylophrya, Endosphaera, Pottsiocles, Pseudogemma, Tachyblaston, and Thecacineta. Free-living and ectocommensal. Migratory stages formed by internal (endogenous) budding. See Kahl (1934b).

Family DENDROSOMATIDAE Fraipont, 1878. A large family of at least 13 genera, of which only Lernaeophrya and Trichophrya have marine representatives. Budding endogenous. 
Family DISCOPHRYIDAE Collin, 1912. At least 14 genera. of which but Corynophrya and Thaumatophrya occur in marine environments.

Family EPHELOTIDAE Kent, 1880. Four genera with marine species: Actinocyathus, Ephelota, Metephelota, and Podocyathus. Budding exogenous, apical, and multiple. Freeliving and ectocommensal on hydroids. See Kahl (1934b).

Family OPHRYODENDRIDAE Stein, 1867. Five genera with marine species: Collinophrya, Dendrosomides, Ophryodendron, Rhabdophrya, and Trophogemma. Free-living and ectocommensal. Budding exogenous. See Jankowski (1970).

Family PHALACROCLEPTIDAE Kozloff, 1966. One species, Phalacrocleptes verruciformis, originally considered a member of the order Thigmotrichida. Ectocommensal on the polychaete Schizobranchia. See Kozloff (1966).

Family PODOPHRYIDAE Haekel, 1866. At least five genera with marine species: Lecanophrya, Ophryocephalus, Paracineta, Parapodophrya, and Podophrya. Free-living and ectocommensal. Migratory stages formed by external (exogenous) budding. Development of stalk may vary within a genus.

Silenella ovoidea Fenchel, 1965 (couplet 97) may be a ciliated motile stage of an unidentified suctorian. Described as ectocommensal on an amphipod. See Fenchel (1965b).

\section{Order Apostomatida}

Family ASKOELLIDAE Jankowski, 1967. Three genera: Askoella, Conidiophrys, and Phthorophrya. Members of the genus Askoella are commensal on barnacles and amphipods (Fenchel, 1965b; Jankowski, 1967a) and according to Jankowski represent neotenic tomites of the order Apostomatida with a secondary cytostome. Conidiophrys has been considered to be a trichostome (Chatton and Lwoff, 1936). The trophont bears no cilia and is attached to hairs and papillae of appendages of amphipods and isopods. According to Jankowski (1967b) the ciliated stages resemble members of the order Apostomatida but with a significantly different life cycle. Consequently, Jankowski (1967b) placed this animal in a suborder by itself. Nonciliated adult stages of Conidiophrys are known to occur on Corophium, Gammarus, and Idothea.

Family FOETTINGERIIDAE Chatton, 1911. At least 14 genera represented in marine habitats. Ciliates found in body fluids of copepods, amphipods, crabs, hermit crabs, and sea anemones. Life cycle complex, polymorphic, with encysted stages. See Chatton and Lwoff (1935).

Family OPALINOPSIDAE Hartog, 1906. Three genera: Chromidina, Cyrtocaryum, and Opalinopsis; endocommensal in cephalopods, coelenterates, ctenophores, and polychaetes. Chromidina occurs in cephalopods, Sepia, Loligo, and Illex. See Chatton and Lwoff (1935). Cyrtocaryum occurs in the lateral caeca of the digestive tube of the polychaete Halosydna. The life cycle includes a tomite with a group of five to six fine, short ciliary rows once division allows size to fall below $40 \mu \mathrm{m}$. Tomites are liberated into free seawater; they are asymmetrical, with a long caudal cilium. See Fauré-Fremiet and Mugard (1949).

\section{Order Astomatida}

Family ANOPLOPHRYIDAE Cépède, 1910. At least 12 genera, of which five have marine representatives. Members of the genera Anoplophryopsis, Herpetophrya, Herpinella, and Rhizocaryum occur in polychaetes including Cirratulus and Polydora. Members of the genus Perseia occur in Phascolosoma. See Cépède (1910), Kahl (1933), and Puytorac (1954).

Family HAPTOPHRYIDAE Cépède, 1923. About eight genera, of which Lachmannella and Steinella have marine representatives in turbellarians. See Sikora (1963) and Corliss, Puytorac, and Lom (1965).

Family HOPLITOPHRYIDAE Cheissin, 1830. Includes over 30 genera (including those sometimes placed in the family INTOSHELLINIDAF Cépède, 1910), of which at least five have marine species: Buetschliella, Durchoniella, Hovassiella, Helella, and Spirobuetschliella. Marine members of the family are endocommensal in the gut of polychaetes, Ophelia, Cirratulis, Polydora, and Potamoceros. 


\section{Order Hymenostomatida}

Family CINETOCHILIDAE Perty 1852. Two genera, of which one, Cinetochilum, with one marine species. Free-living. See Gelei (1940).

Family COHNILEMBIDAE Kahl, 1933. Includes only'the genus Cohnilembus. Free-living. See Borror (1961, 1963).

Family ENTORHIPIDIIDAE Madsen, 1931. Contains at least the genus Entorhipidium, occurring in the gut of sea urchins. See Berger (1961b).

Family FRONTONIIDAE Kahl, 1926. Eight genera; two with marine species: Frontonia and Frontoniella. Widespread, free-living. See Roque (1961).

Family LOXOCEPHALIDAE Jankowski, 1964. At least two genera with marine species, Dexiotricha and Loxocephalus. Free-living. Cardiostomatella may belong here also. See Jankowski (1964a) and Fauré-Fremiet (1968).

Family OPHRYOGLENIDAE Kent, 1880. Possibly four genera; only one, Ophryoglena, in the marine habitat. Free-living in brackish waters; some species histophagic. See Roque (1961).

Family PARAMECIIDAE Dujardin, 1841. One genus, Paramecium, with many species, of which $P$. woodruffi and $P$. calkinsi occur in brackish water. Free-living. See Wichterman (1953).

Family PHILASTERIDAE Kahl, 1931. The boundaries between this family and the URONEMATIDAE are unclear. The members of the genera Philaster, Philasterides, and Porpostoma form a natural group within the PHILASTERIDAE. Anophrys salmacida may belong here also (Small, 1967). Additionally, members of the genera Glauconema, Helicostoma, Paranophrys, Parauronema, and Potomacus, most of which have been placed in the URONEMATIDAE, may be members of the PHILASTERIDAE. Freeliving and endocommensal in sea urchins, sometimes found in association with hydroids and anemones, some histophagic.

Family PLEURONEMATIDAE Kent, 1880. Genera with marine members are Cristigera,
Cyclidium, Histiobalantium, Pleurocoptes, Pleuronema, and Schizocalyptera. The genus Cyclidium is sometimes placed in the family CYCLIDIIDAE Ehrenberg, 1838. The genus Peniculistoma, sometimes considered in the order Thigmotrichida, may also belong in this family. Free-living and commensal on mussels and sea urchins. See Fauré-Fremiet (1961a), Dragesco (1968), and Borror (1963).

Family PSEUDOCOHNILEMBIDAE Evans and Thompson, 1964. On the basis of similarities in morphogenesis, Pseudocohnilembus spp. and Anophrys sarcophaga belong here (Evans and Thompson, 1964; Small, 1967). On the basis of interphase morphology, Paralembus and Cryptochilidium cuenoti may also belong here. Free-living and endocommensal in sea urchins (C. cuenoti occurs in the esophagus of the sipunculid Phascolosoma). See Berger (1961a, 1965) and Mugard (1949).

Family TETRAHYMENIDAE Corliss, 1952. Includes at least six genera; two with marine species: Paratetrahymena and Platynematum. Recently Corliss (1961) split several genera from this family and placed them in the family GLAUCOMIDAE. See Borror (1962), Corliss (1961), Czapik (1968), and Thompson (1963).

Family URONEMATIDAE Thompson, 1964. The boundaries between this family and the PHILASTERIDAE are unclear, but members of the genera Uronema and Uropedalium form a well-defined group within this family. In addition, members of the genera Glauconema, $M i$ amiensis, Parauronema, and Potomacus have been placed here. Free-living, sometimes found in association with hydroids and anemones. See Thompson (1964a, b, 1966) and Thompson and Berger (1965).

In addition to the hymenostomes assigned to the families above, members of several genera (Biggaria, Cryptochilum, Entodiscus, and Madsenia, all endocommensals of sea urchins) are considered here as hymenostomes with no assigned familial status (Berger, 1961c).

Recently, Small erected a new order Scuticociliatida for certain hymenostome and thigmotrich families apparently related by particular features of stomatogenesis (Small, 1967). 


\section{Order Thigmotrichida}

Family ANCISTROCOMIDAE Chatton and Lwoff, 1939. About 23 genera; 12 with marine representatives: Colligocineta, Crebricoma, Goniocoma, Heterocineta, Holocoma, Hypocomagalma, Hypocomella, Hypocomides, Hypocomina, Insignicoma, Isocomides, and Raabella. Typically ectocommensal on gills of bivalves. See Fenchel (1965a), Kozloff (1965 and earlier papers), and Raabe (1970b).

Family CONCHOPHTHIRIDAE Kahl, 1934. At least four genera; one, Cochliophilus, with a marine representative endocommensal in Phytia, a tidal marsh pulmonate snail of the west coast. See Kahl (1934a) and Raabe (1963b).

Family CRATERISTOMATIDAE Jankowski, 1967. Contains Crateristoma kindi, a carnivore on prostome ciliates found in association with ba1"nacles. See Jankowski (1968).

Family HEMISPEIRIDAE König, 1894. Contains at least 17 genera, of which nine have marine members: Ancistrospira, Ancistrum, Boveria, Hemispeira, Isselina, Orchitophrya, Plagiospira, Proboveria, and Protophyra. Most are ectocommensal on gills of bivalves; one is endozoic in echinoderms. Nucleocorbula adherens Santhakumari and Balakrishnan Nair, 1970, for which the authors erected the family NUCLEOCORBULIDAE, keys out here. See Lom, Corliss, and Noirot-Timothée (1968), Fenchel (1965a), and Raabe (1970a).

Family HYPOCOMIDAE Bütschli, 1889. Three genera; two, Heterocoma and Parahypocoma, with marine representatives; ectocommensal on solitary and colonial peritrichs, and in branchial cavity of ascidians. See Chatton and Lwoff (1949).

Family HYSTEROCINETIDAE Diesing, 1866. Members of this family (at least 10 genera) are typically endocommensal in terrestrial and freshwater oligochaetes. See Raabe (1949) and Kozloff (1960).

Family SPHENOPHRYIDAE Chatton and Lwoff, 1921. Four genera with marine representatives: Gargarius, Lwoffia, Pelecophrya, and Sphenophrya; ectocommensal on gills of bivalves. Mature form with no cilia (except in genus Lwoffia), but budded larval forms with several rows of cilia. See Kozloff (1955), Dobrzanska (1961), and Raabe (1970b).

Family THIGMOPHRYIDAE Chatton and Lwoff, 1923. Two genera, Conchophyllum and Thigmophyra, with marine representatives; ectocommensal on gills of bivalves. Undulating membrane difficult to observe in life. See Fenchel (1965a).

The genus Peniculistoma, sometimes considered to be a member of this order, is included here in the family PLEURONEMATIDAE (order Hymenostomatida). Recently, Small erected a new order Scuticociliatida for certain hymenostome and thigmotrich families apparently related by particular features of stomatogenesis.

\section{Order Peritrichida}

Family EPISTYLIDIDAE Kahl, 1933. Fourteen genera, of which at least three have marine representatives: Epistylis, Opisthostyla, and Rhabdostyla. They occur attached to algae or the outer surfaces of copepods and barnacles, (Epistylis), on stalks of ascidians (Opisthostyla), and on polychaetes, midge larvae, and sea cucumbers (Rhabdostyla). Individuals solitary and colonial. See Kahl (1935); Lom (1964).

Family LAGENOPHRYIDAE Bütschli, 1889. At least two genera; one, Lagenophrys, with marine representatives, ectocommensal on crustaceans. See Couch (1967).

Family SCYPHIDIIDAE Kahl, 1933. Ten genera, of which three have marine representatives. Members of the genus Ellobiophrya occur on Donax; Paravorticella occurs on polychaetes; Scyphidia occurs on snails and polychaetes. See Kahl (1935).

Family URCEOLARIIDAE Dujardin, 1941. Subfamily Urceolarinae contains the genera. Urceolaria, Leiotricha, Trichodinopsis, and Polycycla that occur as ectocommensals on marine invertebrates, on gills and respiratory surfaces of marine invertebrates, in the gut of snails, and in the gut of sea cucumbers, respectively. The subfamily Trichodininae contains eight genera, of which seven have marine representatives. Members of the genera Dipartiella, Trichodinella, and Tripartiella occur attached to fish gills; 
members of the genera Paravauchomia, Poljanskina, Tripartiella, and Vauchomia occur in the urinary bladder of fish; and members of the genus Trichodina are found in association with a wide variety of hosts. See review by Raabe (1963a).

Family VAGINICOLIDAE de Fromentel, 1874. Ten genera, of which six have marine representatives. Members of the genera Caulicola and Thuricola are free-living. Cothurnia, Platycola, Pyxicola, and Vaginicola occur attached to red or green algae, as well as the outer surfaces of various invertebrates, including crustaceans, polychaetes, hydroids, and snails. See Kahl (1935).

Family VORTICELLIDAE Ehrenberg, 1838. Eight genera; three with marine representatives. Members of the genera Carchesium and Vorticella are free-living. Members of the genus Zoothamnium are free-living and ectocommensal on crustaceans and hydroids. See Kahl (1935). Myonemes in colonial forms usually continuous, except in the genus Carchesium.

\section{Order Heterotrichida}

Family CAENOMORPHIDAE Poche, 1913. Three genera; one, Caenomorpha, with marine representatives. Occur in regions of low oxygen concentration. Free-living. See Jankowski (1964b).

Family CHATTONIDIIDAE VilleneuveBrachon, 1940. One genus, Chattonidium, freeliving. See Villeneuve-Brachon (1940).

Family CONDYLOSTOMATIDAE Kahl in Doflein and Reichenow, 1929. One genus, Condylostoma, widespread and free-living. See Borror (1963).

Family FOLLICULINIDAE Dons, 1914. Members of this family are grouped into at least 30 genera (listed by Corliss, 1961), all marine. They are ectocommensal on various invertebrates.

Family LICNOPHORIDAE Bütschli, 1887. One genus, Licnophora, ectocommensal on snails, mussels, sea cucumbers, marine worms, and other invertebrates. See Villeneuve-Brachon (1940).
Family METOPIDAE Kahl, 1932. Six genera; one, Metopus, with marine species. Freeliving in areas of low oxygen concentration. See Jankowski (1964b).

Family PERITROMIDAE Stein, 1867. Two genera; one, Peritromus, with marine species. Free-living. See Borror (1963) and Tuffrau (1967b) .

Family SPIROSTOMATIDAE Stein, 1867. At least eight genera, of which four have ma. rine representatives: Blepharisma, Gruberia, Parablepharisma, and Anigsteinia. Large, elongate, free-living animals. See Isquith (1968). The genus Protocruzia, usually placed in this family, is sufficiently aberrant to warrant transfer to a different family. They are freeliving, benthic, small, and fragile. See Ammermann (1968).

Family STENTORIDAE Carus, 1863. Four genera; three with marine species: Climacostomum, Fabrea, and Stentor. They occur primarily in areas of low salinity. See Kahl (1932).

\section{Order Odontostomatida}

Family EPALXELLIDAE Corliss, 1960. Three genera; one, Epalxella, with marine species. Free-living, in areas of low oxygen concentration. See Jankowski (1964b).

Family MYLESTOMATIDAE Kahl, 1932. Two genera; one, Mylestoma, with marine species. Free-living, in areas of low oxygen concentration. See Jankowski (1964b).

\section{Order Oligotrichida}

Family HALTERIIDAE Claparède and Lachmann, 1858. Seven genera; four with marine representatives: Cephalotrichidium, Metastrombidium, Strombidium, and Tontonia. These are typically pelagic. Members of the genus Strombidium are widespread, ubiquitous, and in some cases benthic. See Kahl (1932). Recently members of this family with a girdle of trichites and polygonal cortical platelets, including Strombidium and Tontonia, were placed in the family STROMBIDIIDAE. See FauréFremiet (1969). 
Family STROBILIDIIDAE Kahl in Doflein and Reichencw, 1929. Six genera, of which three hare marine species: Ciliospira, Lohmanniella, and Strobilidium. Typically pelagic, planktonic. See Kahl (1932).

\section{Order Tintinnida}

Families in this order are differentiated on the basis of the morphology of the lorica. See Kofoid and Campbell (1929), Schwarz (1964), Loeblich and Tappan (1968), and Tappan and Loeblich (1968). Members of this order generally are pelagic, planktonic. Many genera are known only as fossils.

Family CODONELLIDAE Kent, 1882. At least five marine genera: Codonaria, Codonella, Codonopsis, Rhizodomus, and Tintinnopsis.

Family CODONELLOPSIDAE Kofoid and Campbell, 1929. Eight genera; at least three with marine species: Codonellopsis, Laackmanniella, and Stenosemella.

Family COXLIELLIDAE Kofoid and Campbell, 1929. Eight genera; seven with recent marine representatives: Climacocylis, Coxliella, Helicostomella, Metacylis, Stylicauda, Favelloides, and Poroecus.

Family CYTTAROCYLIDIDAE Kofoid and Campbell, 1929. Only Cyttarocylis.

Family DICTYOCYSTIDAE Kent, 1881. Three genera with marine species: Dictyocysta, Luminella, and Wangiella.

Family EPIPLOCYLIDIDAE Kofoid and Campbell, 1929. Three genera with marine representatives: Epicancella, Epiplocylis, and Epiplocyloides.

Family PETALOTRICHIDAE Kofoid and Campbell, 1929. Six genera with marine representatives: Acanthostomella, Ascampbelliella, Luxiella, Niemarshallia, Petalotricha, and Wailesia.

Family PTYCHOCYLIDIDAE Kofoid and Campbell, 1929. Four genera with marine representatives: Cymatocylis, Favella, Protocymatocylis, and Ptychocylis.
Family RHABDONELLIDAE Kofoid and Campbell, 1929. Four marine genera: Epirhabdonella, Protorkabdonella, Rhabdonella, and Rhabdonellopsis.

Family TINTINNIDAE Claparède and Lachmann, 1858. About 23 genera with marine representatives (listed by Tappan and Loeblich, 1968).

Family TINTINNIDIIDAE Kofoid and Campbell, 1929. Two marine genera: Leprotintinnus and Tintinnidium.

Family UNDELLIDAE Kofoid and Campbell, 1929. Seven genera with marine species: Amplectella, Amplectellopsis, Cricundella, Micrundella, Proplectella, Undella, and Undellopsis.

Family XYSTONELLIDAE Kofoid and Campbell, 1929. Four genera with marine species: Parafavella, Parundella, Xystonella, and Xystonellopsis.

\section{Order Hypotrichida}

Family EUPLOTIDAE Ehrenberg, 1838. Eleven genera, each with marine representatives: Aspidisca, Certesia, Diophrys, Discocephalus, Euplotaspis, Euplotes, Euplotidium, Gastrocirrhus, Paraeuplotes, Swedmarkia, and Uronychia. Most are benthic and free-living. See Borror (1963, 1965a, 1968b, and 1972) and Deroux and Tuffrau (1965).

Family HOLOSTICHIDAE Fauré-Fremiet, 1961. At least six genera with marine species: Holosticha, Keronopsis, Paraholosticha, Trichotaxis, Uroleptopsis, and Uroleptus. Free-living. See Borror (1972a).

Family OXYTRICHIDAE Ehrenberg, 1838. Marine genera include: Ancystropodium, Gastrostyla, Histriculus, Laurentia, Onychodromus, Oxytricha, Parastylonychia, Stylonychia, Tachysoma, and Trachelostyla. Free-living and benthic. See Borror (1972a) and Fauré-Fremiet (1961b).

Family PSILOTRICHIDAE Bütschli, 1889. Three genera: Caryotricha, Kitricha, and Psilotricha, all marine. ,Free-living. See Kahl (1932). 
Family SPIROFILIDAE Gelei, 1929. Seven genera; three with marine species: Stichotricha, Strongylidium, and Urostrongylum. Free-living and benthic.

Family UROSTYLIDAE Bütschli, 1889. At least seven genera with marine representatives: Amphisiella, Balladyna, Banyulsella, Epiclintes, Lacazea, Paraurostyla, and Urostyla. Members free-living and benthic. See Borror (1972a).

\section{SELECTED BIBLIOGRAPHY}

AGAMALIEV, F. G.

1967. Faune des ciliés mésopsammiques de la côte ouest de la Mer Caspienne. Cahiers Biol. Mar. 8:359-402. [Morphology of many species; new species described.]

AMMERMANN, VON D.

1968. Die Kernverhältnisse des Ciliaten Protocrucia depressa n. sp. Arch. Protistenkd. 110:434-438. [Includes careful description of morphology.]

BERGER, J.

1961a. The comparative buccal morphology of certain hymenostome ciliates entocommensal in echinoids. Proc. First Int. Cong. Protozool. p. 86-88. [Describes ciliature of buccal cavity in Cryptochilum and Biggaria spp.]

1961b. Stomatogenic evidence for the hymenostome affinities of the genus Entorhipidium Lynch. J. Protozool. 8 (Suppl.): 11. [Morphology of this ciliate from sea urchins.]

1961c. Systematic reassignment, based on buccal morphology of two species of ciliates entocommensal in echinoids. J. Protozool. 8(Suppl.):11. [Transfers Entodiscus and Madsenia from the Trichostomatida to the Hymenostomatida.]

1961d. Morphology and systematic position of Schizocaryum dogieli, a ciliate entocommensal in strongylocentrotid echinoids (Ciliata: Trichostomatida). J. Protozool. 8:363-369. [Places it in the trichostome family PLAGIOPYLIDAE.]

1965. Infraciliary morphology of a littleknown echinophilous hymenostome ciliate from the Indo-West Pacific. Proc. Sec- ond Int. Conf. Protozool. No. 255. [Discusses morphology of Cryptochilidium polynucleata.]

BORROR, A. C.

1961. Feeding apparatus of the ciliate Cohnilembus verminus (Müller). Bull. Assoc. Southeastern Biol. 8:21. [Description of buccal and somatic ciliature.]

1962. Ciliate Protozoa of the Gulf of Mexico. Bull. Mar. Sci. Gulf Caribb. 12: 333-349. [List of recorded species and suggested synonymies.]

1963. Morphology and ecology of the benthic ciliated Protozoa of Alligator Harbor. Florida. Arch. Protistenkd. 106:465-534. [Morphology of many species; four new species described.]

1965a. Morphological comparison of $D i$ ophrys scutum (Dujardin, 1841) and Diophrys peloetes n. sp. (Hypotrichida, Ciliophora). J. Protozool. 12:60-66. [Intraspecific variations tabulated.]

1965b. New and little-known tidal marsh ciliates. Trans. Am. Microsc. Soc. 84: 550-565.

1968a. Nigrosin- $\mathrm{HgCl}_{2}$-Formalin; a stainfixative for ciliates (Protozoa, Ciliophora). Stain Technol. 43:293-295. [Formula for a method that stains cilia and cortical sculpturing black against a white background.]

1968b. Systematics of Euplotes (Ciliophora, Hypotrichida) ; toward union of the old and the new. J. Protozool. 15:802808. [Discussion of morphology of four species, showing importance of cortical features (viewed prior to dependence upon silver line system) in identification of species.]

1969. Application of the stain-fixative Nigrosin- $\mathrm{HgCl}_{2}-\mathrm{F}$ ormalin to fragile or contractile ciliates. Trans. Am. Microsc. Soc. 88:454-458. [Modification of the fixation and relaxation methods applied to above method.]

1972a. Revision of the order Hypotrichida (Ciliophora, Protozoa). J. Protozool. 19:1-23. [Lists 310 species distributed among 51 genera and 6 families. All families and genera are diagnosed and illustrated and synonymies are listed for each species.] 
BORROR-Cont.

1972b. Ciliates of New Hampshire tidal marshes. Acta Protozool. 10:29-71. [About 100 species listed; morphology and autecology of over $30 \mathrm{spp}$. discussed; 4 new species.]

CANELLA, M. F.

1960. Contributi alla conscenza dei Ciliati.

III. Contributo ad una revisione dei generi Amphileptus, Hemiophrys e Lionotus (Ciliata, Holotricha, Gymnostomata). Ann. Univ. Ferrara, Sez. 3, Biol. Anim. 2:47-95. [Systematics of the Amphileptidae; a lengthy treatise.]

CEPEDE, C.

1910. Recherches sur les infusoires astomes. Anatomie, biologie, éthologie parasitaire, systématique. Arch. Zool. Exp. Gén. (Ser. 5) 3:341-609. [An early but important work describing many species of the order Astomatida.]

CHATTON, E., and A. LWOFF.

1935. Les ciliés apostomes. Première partie. Aperçu historique et général. Étude monographique des genres et des éspeces. Arch. Zool. Exp. Gén. 77:1-453. [A classic monograph on the Apostomatida.]

1936. Les Pilisuctoridae Chatton et Lwoff. Ciliés parasites des poils séchéteurs des Crustaces Edriophthalmes. Polarité, orientation, et desmodexie chez les Infusoires. Bull. Biol. Fr. Belg. 70:86-144. [A description of the life cycle of the nonciliated sessile Conidiophrys.]

1949. Recherches sur les ciliés thigmotriches. Arch. Zool. Exp. Gén. 86:169253, 393-495. [An important monograph on the members of the order Thigmotrichida.]

CORLISS, J. O.

1953. Silver impregnation of ciliated protozoa by the Chatton-Lwoff technic. Stain Technol. 28:97-100. [A redescription of the classical French silver method.]

1959. An illustrated key to the higher groups of the ciliated Protozoa, with definition of terms. J. Protozool. 6:265-281.

1961. The ciliated Protozoa; characterization, classification, and guide to the literature. Pergamon Press, Inc., N.Y. 310 p.
[Contains impcrtant coverage of history, systematics, and bibliographic sources for the entire class.]

CORLISS, J. O., P. de PUYTORAC, and J. LOM. 1965. Resolution of persistant taxonomic and nonmenclatural problems involving ciliate Protozoa assignable to the astome family Haptophryidae Cépède, 1923. J. Protozool. 12:265-273. [Morphology of Steinella and Lachmanella discussed.]

COUCH, J. A.

1967. A new species of Lagenophrys (Ciliatea: Peritrichida: Lagenophryidae) from a marine crab, Callinectes sapidus. Trans. Am. Microsc. Soc. 86:204-211. [Morphology of cell and lorica discussed.]

CZAPIK, A.

1968. La famille Tetrahymenidae et son importance dans la systématique et l'év.olution des ciliés. Acta Protozool. 5:315358. [A recent review of the family Tetrahymenidae.]

DEROUX, G.

1970. La série "Chlamydonellienne" chez les Chlamydodontidae (Holotriches, CYRTOPHORINA Fauré-Fremiet). Protistologica 6:155-182.

DEROUX, G., and M. TUFFRAU.

1965. Aspidisca orthopogon n. sp. Revision des certains mécanismes de la morphogenèse à l'aide d'une modification de la technique au Protargol. Cahiers Biol. Mar. 6:293-310. [Important descriptions of morphogenesis in this hypotrich.]

DOBRZANSKA, J.

1961. Further study on Sphenophrya dreissenae Dobrzanska 1958 (Ciliata, Thigmotricha). Acta Parasitol. Pol. 9: 117-140. [Comparative morphology of many thigmotrichs, including ciliated tomites.]

DOBRZANSKA-KACZANOWSKA, J.

1963. Comparaison de la morphogenèse des Ciliés: Chilodonella uncinata (Ehrbg.), Allosphaerium paraconvexa sp. n. et Heliochona scheuteri (Stein). Acta Protozool. 1:353-394. [On comparative mcrphology of the gymnostones and the chonotrichs.]

DRAGESCO, J.

1960. Les ciliés mesopsammiques littoraux (Systématique, morphologie, écologie). Trav. Stn. Biol. Roscoff 12 (Nov. Sér.): 
1-356. [A lengthy treatise on sand dwelling ciliates, with descriptions of many new species.]

1963a. Révision du genre Dileptus, Dujardin 1871 (Ciliata: Holotricha) Systématique, Cytologie, Biologie. Bull. Biol. Fr. Belg. 97:103-145. [A recent review of the genus.]

1963b. Compléments a la connaissance des Ciliés mesopsammiques de Roscoff. 1. Holotriches. Cahiers Biol. Mar. 4:91-119. [Morphology: descriptions of new species.]

1966. Observations sur quelques ciliés libres. Arch. Protistenkd. 109: 155-206. [Morphology: descriptions of new species.]

1967. Armature fibrilaire interne chez Hartmannula acrobates Entz (Cilié, holotriche gymnostome). Protistologica 3: 61-65. [Studied this gymnostome with protargol method.]

1968. Les genres Pleuronema Dujardin, Schizocalyptera nov. gen. et Histobalantium Stokes (Ciliés holotriches hyménostomes). Protistologica 4:85-106. [Discussion of intraspecific variation, and descriptions of new species.]

EVANS, F. R., and J. C. THOMPSON, JR.

1964. Pseudocohnilembidae $n$. fam., a hymenstome ciliate family containing one genus, Pseudocohnilembus n.g., with three new species. J. Protozool. 11:344352.

FAURE-FREMIET, E.

1955. La position systématique due genre Balantidium. J. Protozool. 2:54-58. [Considers it a trichostome.]

1961a. Pleurocoptes hydractinae (Ciliata Pleuronematina) et son adaptation structurale a la vie épizoique. Cahiers Biol. Mar. 2:447-52. [Shows its Pleuronemalike buccal ciliature.]

1961b. Protozoologie.-Remarques sur la morphologie comparée et la systématique des Ciliata Hypotrichida. C. R. Acad. Sci., Paris 252:3515-3519. [Brief review of the order, with erection of new families.]

1961c. Protozoologie.-Les Ciliés Cyrtophorina et leur diversification morphologique. C. R. Acad. Sci., Paris 252:3912-
3916. [Distinguishes between the Enchelyidae and the Prorodontidae and discusses other gymnostomes.]

1962a. Le genre Paranassula Kahl (Ciliata, Cyrtophorina). Cahiers Biol. Mar. 3:61-77. [Illustrates its vestibular ciliature.]

1962b. Le genre Trimyema Lackey et les caractéristiques structurales des ciliés Trichostomatida. J. Protozool. 9:146149. [Describes somatic and vestibular ciliature.]

1963. Conchostoma longissimum n.g. n. sp., cilié trichostome psammobie. Cahiers Biol. Mar. 4:193-199. [Describes this extremely elongate form from sand.]

1968. Les genres Dexiotricha Stokes et Loxocephalus Eberhard dans leurs relations auxomorphiques. Protistologica 4: 115-125.

1969. Remarques sur la systématique des ciliés Oligotrichida. Protistologica 5: 345-352. [A review of the order; a new family erected.]

FAURE-FREMIET, E., and H. MUGARD.

1949. Zoologie.-Un infusoire apostome parasite d'un polychete: Cyrtocaryum halosydnae, n. gen., n. sp. C. R. Acad. Sci., Paris 228: 1753-1755. [Morphology, life cycle, and systematics.]

FAURE-FREMIET, E., C. ROUILLER, and M. GAUCHERY.

1956. Structure et origine du pédoncule chez Chilodochona. J. Protozool. 3:188193. [Morphology of this member of the Chonotrichida.]

FENCHEL, T.

1964. Gullmarella faurei n. g., n. sp., a holotrichous ciliate from the intestine of Lamellibranchs. Cahiers Biol. Mar. 5: 311-318. [Morphology of this peculiar trichostome.]

1965a. Ciliates from Scandinavian molluscs. Ophelia 2:71-174. [An important treatise containing morphological details on the many thigmotrichs, and descriptions of new species.]

1965b. On the ciliate fauna associated with the marine species of the amphipod genus Gammarus J. G. Fabricius. Ophelia 2: 281-303. [Morphology; Silenella described.] 
GELEI. G.

1940. Cinetochilum und sein Neuronemensystem. Arch. Protistenkd. 94:57-79. [Shows the buccal apparatus to be Tetrahymena-like.]

HAIRSTON, N. G., and S. L. KELLERMANN. 1964. Paramecium ecology; electromigration for field samples and observations on density. Ecology 45:373-376. [Describes a method for isolating paramecia from bottom sediments based on their locomotion in a weak electrical current.]

ISQUITH, I. R.

1968. Anigsteinia n. g., a member of the family Spirostomatidae. J. Protozool. 15 (Suppl.):26. [Splits this genus from Blepharisma.]

JANKOWSKI, A. W.

1964a. Morphology and evolution of Ciliophora. IV. Sapropelebionts of the family Loxocephalidae fam. nova, their taxonomy and evolutionary history. Acta Protozool. 2:33-58. [Discusses morphology of Dexiotricha and Loxocephalus.]

1964b. Morphology and evolution of ciliophora. III. Diagnoses and phylogenesis of 53 Sapropelebionts, mainly of the order Heterotrichida. Arch. Protistenkd. 107: 185-294. [An important revision cf the Odontostomatida and the Metopus-like heterotrichs.]

1967a. Ciliates from the mantle cavity of Balanus in Barents Sea. Parasitology 1:82-93. [Morphology and systematics, including descriptions of several new species.]

1967b. A new system of the Ciliate Protozoa (Ciliophora). Acad. Sci. USSR, Trav. Zool. Inst. 43:1-52. [A lengthy important treatise defending a reclassification of the ciliates, emphazing a new realignment particularly of many holotrichs.]

1968. Morphology and phylogeny of Crateristoma (Ciliophora: Rhynchodida). Hydrobiol. J. 4:33-41. [Morphological details added to previous description.]

1970. Trophogemma poljansky gen. et sp. n. (Ciliophora, Suctoria) from the shrimp's antennae. Hydrobiol. J. 6: 454-457. [Morphology.]
KAHL, A.

1930-1935. Urtiere oder Protozoa. I: Wimpertiere oder Ciliata (Infusoria). In F. Dahl, Die Tierwelt Deutschlands, $18(1930), 21(1931), 25(1932), 30$ (1935), p. 1-886. [Most important treatise on the morphology and systematics of the ciliates. Attempts to deal with every species, except for marine tintinnids and endozoic ciliates.]

1933. Ciliata libera et ectocommensalia. In G. Grimpe and E. Wagler (Begrundet), Die Tierwelt der Nord- und Ostsee 23:29-146. [This monograph, published in another series, overlaps significantly with the above, but it contains much important morphological and systematics information.]

1934a. Ciliata entocommensalia et parasitica. In G. Grimpe and E. Wagler (Begrundet), Die Tierwelt der Nord- und Ostsee 26:147-183. [Complements the monograph cited above, with coverage on parasitic forms.]

1934b. Suctoria. In G. Grimpe and E. Wagler (Begrundet), Die Tierwelt der Nord- und Ostsee 26:184-226. [An important monograph on the order Suctorida.]

KOFOID, C. A., and A. S. CAMPBELL.

1929. A conspectus of the marine and fresh water Ciliata belonging to the suborder Tintinnoinea, with descriptions of new species principally from the Agassiz expedition to the eastern tropical Pacific, 1904-1905. Univ. Calif. Publ. Zool. 34:1403. [A classical monograph on these planktonic ciliates.]

KOZLOFF, E. N.

1955. Lwoffia cilifera gen. nov., sp. nov., a ciliated member of the family Sphenophryidae (Holotricha: Thigmotricha). Biol. Bull. 108:283-289. [Morphology of a ciliate ectocommensal on mussels.]

1960. Morphological studies on holotrichous ciliates of the family Hysterocinetidae I. Hysterocineta eiseniae Beers and Ptychostomum campelomae sp. nov. J. Protozool. 6:41-50. [Morphology of members of the Astomatida.]

1965. Colligocineta furax gen. nov., sp. nov., an Ancistrocomid cilliate (Holo- 
tricha: Thigmotricha) from the Sabellid polychaete Laonome kröyeri Malmgren. J. Protozool. 12:333-334. [The most recent of a long series of papers by this author on the ciliates that occur in or on marine invertebrates.]

1966. ,Phalacrocleptes verruciformis gen. nov., sp. nov., an unciliated ciliate from the sabellid polychaete Schizobranchia insignis Bush. Biol. Bull. 130:202-210. [A small bizarre protozoon with short tentacles used for attachment to the host.]

KUDO, R. R.

1966. Protozoology. C. C. Thomas, Springfield, $1174 \mathrm{p}$. [The latest edition of this important textbook.]

LOEBLICH, A. R., JR., and H. TAPPAN.

1968. Annotated index to genera, subgenera, and suprageneric taxa of the ciliate order Tintinnida. J. Protozool. 15:185192. [An important source of information of the systematics of this order. See also Tappan and Loeblich, 1968.]

LOM, J.

1964. The morphology and morphogenesis of the buccal ciliary organelles in some peritrichous ciliates. Arch. Protistenkd. 107:131-162. [Applied to protargol method to members of many genera.]

LOM, J., J. O. CORLISS, and C. NOIROTTIMOTHÉE.

1968. Observations on the ultrastructure of the buccal apparatus in thigmotrich ciliates and their bearing on thigmotrichperitrich affinities. J. Protozool. 15:824840. [Members of these two orders closely related due to comparable arrangement of ciliary rows in the buccal cavity.]

MATSUDO, J., and J. L. MOHR.

1965. A new species of Heliochona, $H$. psychra n. sp. (Ciliata: Chonotrichida), from Nuwuk Lake, Alaska. J. Protozool. 12:523-527. [Morphological study.]

1968. Oenophorachona ectenolaemus $\mathrm{n}$. gen., n. sp. and Spirochona halophila n. sp., two new marine chonotrichous ciliates. J. Protozool. 15:280-284. [Morphological study.]

MOHR, J. L., J. A. LEVAGUE, and

H. MATSUDO.

1963. On a new collar ciliate of a gribble: Lobochona prorates n. sp. on Limnoria tripuncta. J. Protozool. 10:226-233. [Morphological study.]

MUGARD, $\mathrm{H}$.

1949. Contribution a l'étude des infusoires hyménostomes histiophages. Ann. Sci. Nat., Zool. Biol. Anim. (Ser. 11) 10:171268. [An important paper illustrating patterns of cilia on several members of the Uronematidae and Philasteridae.]

PRELLE, A.

1963. Observations sur le cilié holotriche Woodruffia rostrata (Johnson et Larson 1938). Arch. Zool. Exp. Gén. 102:239244. [Discussion of this trichostome and its relationship to the Colpodidae.]

PUYTORAC, P. de.

1954. Contribution à l'étude cytologique et taxonomique des Infusoires astomes. Ann. Sci. Nat. Zool. Biol. Anim. 16:85270. [Important recent monograph on the order Astomatida.]

RAABE, Z.

1949. Studies on the family Hysterocinetidae Kiesing. Ann. Mus. Zool. Polon. 14: 21-68. [Important study on the Astomatida.]

1963a. Systematics of the family Urceolariidae Dujardin 1841. Acta Protozool. 1:121-138. [Revision of this family of peritrichs.]

1963b. La stomatogenèse chez Conchophthirus (Ciliata, Thigmotricha). Acta Protozool. 1:139-146. [Morphology and life cycle of this thigmotrich.]

1970a. Ordo Thigmotricha (Ciliata - Holotricha). II. Family Hemispeiridae. Acta Protozool. 7:117-180.

1970b. Ordo Thigmotricha (Ciliata - Holotricha). III. Familiae Ancistrocomidae et Sphenophryidae. Acta Protozool. 7: 385-463. [These two papers are an important recent revision of this order.]

ROQUE, M.

1961. Recherches sur les infusoires ciliés; les hyménostomes peniculiens. Bull. Biol. Fr. Belg. 95:431-519. [An important monograph.]

\section{SCHWARZ, S.}

1964. Die Tintinnoidea. Hydrobiol. 23: 213-245. [A brief but concise and illustrated set of diagnoses to family and genus.] 
SIKORA, J.

1963. Study on the parasitic ciliate Steinella uncinata (Schultze). Acta Protozool. 1:13-20. [Morphology of this member of the family Haptophryidae (order Astomatida).]

SMALL, E. B.

1967. The Scuticociliatida, a new order of the class Ciliatea (Phylum Protozoa, subphylum Ciliophora). Trans. Am. Microsc. Soc. 86:345-370. [A rearrangement of families and genera previously placed in the order Hymenostomatida or the order Thigmotrichida, on the basis of differences in morphogenesis.]

TAPPAN, H., and A. R. LOEBLICH, JR.

1968. Lorica composition of modern and fossil Tintinnida (Ciliata, Protozoa), systematics, geological distribution, and some new tertiary taxa. J. Paleontol. 42: 1378-1394.

THOMPSON, J. C., JR.

1963. The generic significance of the buccal infra-ciliature of the family Tetrahymenidae and a proposed new genus and species, Paratetrahymena wassi. Virginia J. Sci. 14(New Ser.):126-135. [Brief paper on morphology.]

1964a. A redescription of Uronema marinum, and a proposed new family Uronematidae. Virginia J. Sci. 15:80-87. [Morphological study, with photomicrographs.]

1964b. Miamiensis avidus n.g., n. sp., a marine facultative parasite in the ciliate order Hymenostomatida. J. Protozool. 11:378-380. [A species apparently closely allied to Uronema, but differing in exact arrangement of buccal ciliature.]

1966. Glauconema trihymene n.g., n. sp., a hymenostome ciliate from the Virginia coast. J. Protozool. 12:393-394. [Morphology of a Uronema-like ciliate.]

THOMPSON, J. C., and J. BERGER.

1965. Paranophrys marina n.g., n. sp., a new ciliate associated with a hydroid from the Northeast Pacific (Ciliata: Hymenostomatida). J. Protozol. 12: 527-531. [Morphological study.] '

TUFFRAU, M.

1967a. Prefectionnements et practique de la technique d'impregnation au Protargol des infusoires ciliés. Protistologica 3:9198. [A discussion of the use of the protargol or silver proteinate method in staining of ciliates.]

1967b. Les structure fibrillaires somatiques et buccales chez les ciliés hétérotriches. Protistologica 3:369-394. [Use of the protargol technique in elucidating the cilia of the buccal cavity and their associated fibillar systems in various heterotrichs.]

UHLIG, G.

1965. Untersuchungen zur Extraktion der vagilen Mikrofauna aus marinen Sedimenten. Verh. Deutsch. Zool. Ges. 10: 151-157. [Describes use of melt water from seawater ice to drive small metazoans and protozoons from samples of sand.]

VILLENEUVE-BRACHON, S.

1940. Recherches sur les ciliés hétérotriches, cinétome, argyrome, myonèmes. Formes nouvelles ou peu connus. Arch. Zool. Exp. Gén. 82:1-180. [An important monograph on this order.]

WICHTERMAN, R.

1953. The biology of Paramecium. Blakiston Co., Inc., N.Y., 527 p. [An important source of information on this widely known ciliate.] 


\section{SYSTEMATIC INDEX}

Acanthostomella .............. 50

Acineta ...................... 45

Acinetidae ...............44, 45

Acinetopsis .................. 45

Acropisthium ................ 44

Actinocyathus ............. 41,46

Amphileptidae .............. 35, 44

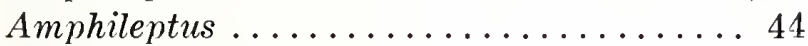

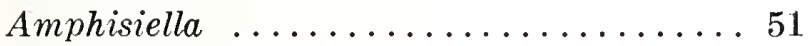

Amplectella .................. 50

Amplectellopsis ............. 50

Ancistrocomidae ........... 14, 36, 40, 48

Ancistrospira ................ 48

Ancistrum .................. 48

Ancystropodium .............. 50

Anigsteinia .................. 49

Anophrys

salmacida ................. 47

sarcophaga .................. 47

Anoplophryidae ............. 15, 46

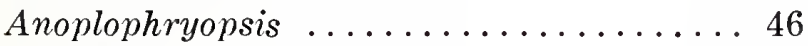

Apostomatida ..............45, 46

Ascampbelliella ................ 50

Askenasia .................... 44

Askoella ................ 34,46

Askoellidae .............. 34, 40,46

Aspidisca ................... 50

Astomatida ................ 2,46

Atopochilodon ................... 44

Balantidiidae ............... 11, 45

Balantidium ................. 45

Balladyna ................. 51

Banyulsella ................. 51

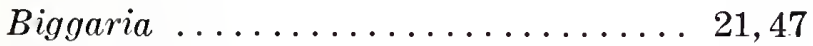

Blepharisma .................. 49

Boveria .................... 48

Brandtiella ................... 24

Brooklynella ................... 44

Buetschliella .................. 46

Caenomorpha ................... 49

Caenomorphidae ............. 39, 49

Carchesium ................. 49

Cardiostomatella ............. 47

Caryotricha ................. 50

Caulicola .....................449

Cephalotrichidium ............... 49

Certesia ...................... 50

Cestus veneris ................. 45

Chaenea ......................444

Chattonidiidae ............. 16,49
Chattonidium ................ 49

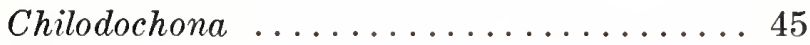

Chilodochonidae ............. 31, 45

Chilodonatella ................. 44

Chilodonella .................. 44

Chilodontopsis .................. 44

Chilophrya .................... 44

Chlamydodon .................... 44

Chlamydodontidae ............. 33, 44

Chlamydonella ................. 44

Choanostoma ................ 44

Chonotrichida .............. 34, 45

Chromidina .................... 44

Ciliofaurea .................... 44

Ciliospira ................... 50

Cinetochilidae $\ldots \ldots \ldots \ldots \ldots \ldots \ldots 33,47$

Cinetochilum ............... 47

Cirratulus .....................446

Clathrostomatidae .......... 11,45

Climacocylis ................ 50

Climacostomum ................ 49

Cochliophilus ............... 48

Codonaria ................... 50

Codonella .................... 50

Codonellidae .............. 25, 50

Codonellopsidae ..............24,50

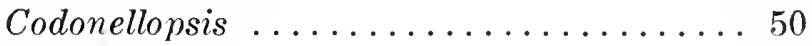

Codonopsis .................. 50

Coelosomides ................... 45

Coelosomididae ............. 7, 45

Cohnilembidae .............. 20,47

Cohnilembus ................ 47

Colepidae ............... 8,44

Coleps ..................... 44

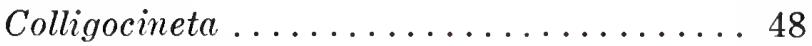

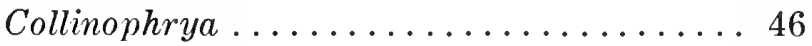

Colpoda ................... 45

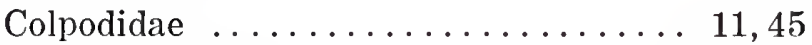

Conchophthiridae .......... 13, 22, 48

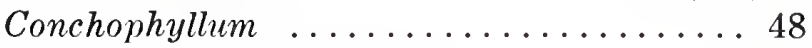

Conchostoma longissimum ........ 13, 45

Condylostoma ................. 49

Condylostomatidae ........... 16, 49

Conidiophrys ............2, 34, 40, 46

Corlissia ................... 45

Corophium ................. 46

Corynophrya ................ 46

Cothurnia ................... 49

Coxliella ..................... 50

Coxliellidae ............ 24, 26, 50 
Crateristoma hindi

48

$\mathrm{Cl}$ ateristomatidae

35,48

Crebriscoma

48

Cricundella

Cristigera

47

Cmyptochilidium cuenoti..

20

Cryptochilum

20,47

Cryptopharynx

Ctenoctophrys

Cyclidiidae

Cyclidium

Cyclotrichium

Cymatocylis

Cyrtocaryum

halosydnae

Cyttarocylididae

Cyttarocylis

Dactylophrya

Dendrosomatidae

Dendrosomides

Dexiotricha

Dictyocysta

Dictyocystidae

Didiniidae.

Didinium

Dileptus

Diophrys

Dipartiella

Discocephalus

Discophryidae

Donax

Durchoniella

Dysteria

Dysteriidae

Ebalia

Ellobiophrya

Enchelyidae

Enchelyodon

Enchelys

Endosphaera

Entodiscus

Entorhipidiidae

Entorhipidium

Epalxella

Epalxellidae

Ephelota

Ephelotidae

Epicancella

Epiclintes

Epiplocylididae

Epiplocylis
Epiplocyloides .............. 50

Epirhabdonella .............. 50

Epistylis .................... 48

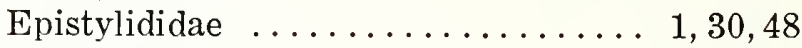

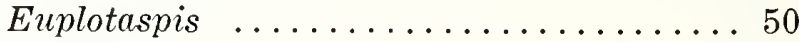

Euplotes .................... 50

Euplotidae ............... 37, 50

Euplotidium .................. 50

Fabrea ...................... 49

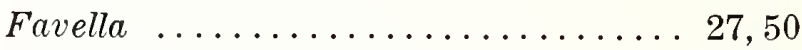

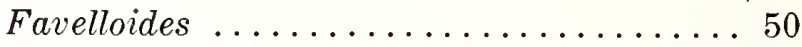

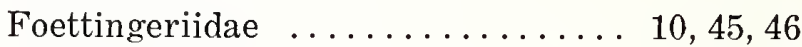

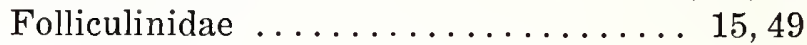

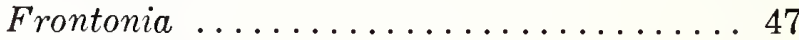

Frontoniella .................. 47

Frontoniidae ............. 18,47

Gammarus ................. 46

Gargarius .................... 48

Gastrocirrhus .................... 50

Gastrostyla .................... 50

Geleia .................... 45

Geleiidae .............. 2, 12, 45

Glaucomidae ............... 47

Glauconema ................... 47

Goniocoma ................... 48

Gruberia ................... 49

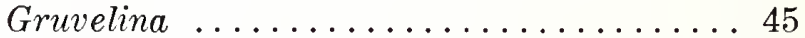

Gullmarella faurei ............ 13, 45

Gymnostomatida ............. 44, 45

Halosydna ................... 46

Halteriidae ................. 29, 49

Haptophryidae .............. 14, 46

Hartmannula ................... 44

Helella ..................... 46

Helicoprorodon ................ 44

Helicostoma ............... 47

Helicostomella .............. 50

Heliochona .................... 45

Hemiophrys ................... 44

Hemispeira ................... 48

Hemispeiridae ............ 22, 38, 48

Herpetophrya ............... 46

Herpinella ................... 46

Heterocineta ................ 48

Heterocoma ............... 48

Heterotrichida ............ 34, 49

Histiobalantium ................ 47

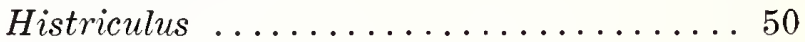

Holocoma ...................... 48

Holophrya ................. 44

Holosticha .................... 50

Holostichidae ............ 36,50 
Hoplitophryidae

$1,14,46$

Hovasseiella

..... 46

Hymenostomatida

$2,5,47,48$

Hypocomagalma

Hypocomella

Hypocomidae

Hypocomides

Hypocomina

Hypotrichida

Hysterocinetidae

Idothea

Ileonema

Illex

Insignicoma

Intoshellinidae

Isocomides

Isselina

Kentrochona

Kentrophoros

Keronopsis

Kiitricha

Laackmanniella

Lacazea

Lachmannella

Lacrymaria

Lagenophryidae

Lagenophrys

Lagynophrya

Lagynurus

Laurentia

Lecanophrya

Lechriopyla

Leiotricha

Leprotintinnus .................... 50

Lernaeophrya ................... 45

Licnophora . ................. 49

Licnophoridae ............ 29,49

Liliimorpha ................ 44

Limnoria . . . . . ............... 45

Litonotus .................... 44

Lobochona ..................... 45

Lohmanniella .................. 50

Loligo . . . . . . . . . . . . . . . . 46

Longitricha ................... 44

Loxocephalidae ............ 19,47

Loxocephalus .................. 47

Loxodes . . . . . . . . . . . . . . . . . . . . . 44

Loxodidae ............... 2, 33, 44

Loxophyllum . . . . . . . . . . . . . . 44

Luminella ................... 50

Luxiella ...................... 50
Lwoffia .................... 48

cilifera .................. 40

Lynchella ................... 44

Madsenia ................ 47

Mesodinium ................ 44

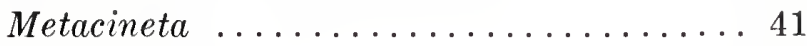

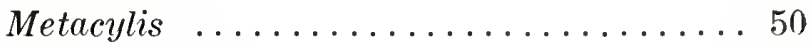

Metacystidae .............. 9,44

Metacystis ................ 44

Metastrombidium .............. 49

Metephelota ................. 46

Metopidae ................ 17, 49

Metopus .................. 49

Miamiensis ............... 47

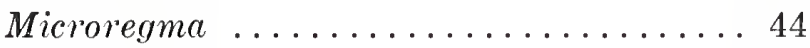

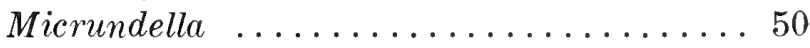

Mirodysteria ................ 44

Monodinium ................ 44

Mylestoma ................ 49

Mylestomatidae ............. 39,49

Nannophrya ................... 44

Nassula ...................... 44

Nassulidae $\ldots \ldots \ldots \ldots \ldots \ldots \ldots \ldots 6,10,44$

Nassulopsis ................ 44

Nebalia ................. 45

Nephrocerca ................. 45

Niemarshallia ............... 50

Nucleocorbula adherens ............448

Nucleocorbulidae ................ 48

Odontochlamys ................ 44:

Odontostomatida ............... 49

Oenophorachona ................ 45

Oligotrichida ................ 49

Onychodromus ................. 50

Opalinopsidae ............ 1, 13, 14, 46

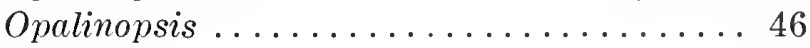

Ophelia .................. 46

Ophryocephalus ............... 46

Ophryodendridae ........... 1,42,46

Ophryodendron ............... 46

Ophryoglena .................. 47

Ophryoglenidae ............ 18, 47

Opisthostyla ............... 48

Orchitophyra ............... 48

Orthodonella ................. 44

Oxytricha ................. 50

Oxytrichidae .................. 37,50

Parablepharisma ................ 49

Parachilodonella ................ 44

Paracineta ................ 41, 46

Paradileptus ................... 44

Paraeuplotes ................. 50 
Parafarella

Paraholosticha

50

Parahypocoma

50

Paralembus

48

Parameciidae

Paramecium

18,47

uoodruffi.

calkinsi

Paranassula

Paranassulidae

Paranophrys

Parapodophyra

Paraspathidium

Parastylonychia

Paratetrahymena

Paratrochilia

Parauronema

Paraurostyla

Paravauchomia

Paravorticella

Parundella

Pelatractus

Pelecophrya 44

Peniculistoma

$22,47,48$

Pericaryon cesticola

12,45

Peritrichida

$1,29,48$

Peritromidae

34,49

Peritromus

Perseia

Petalotricha 50

Petalotrichidae 27,50

Phalacrocleptes verruciformis . 46

Phalacrocleptidae

43,46

Phascolosoma 46,47

Philaster . 47

Philasteridae

21,47

Philasterides

47

Phthorophrya

34,46

Phytia 48

Pithothorax

Placus 44 socialis

Plagiocampa

Plagiopyla

Plagiopylidae

$11,12,45$

Plagiopyliella

Plagiospira

Platycola

Platynematum

Platyophrya 44

Pleurocoptes 22,47

Pleuronema
Pleuronematidae $19,22,47,48$

Podocyathus 41,46

Podophrya 46

Podophryidae $41,43,46$

Poljanskina 49

Polycycla 48

Polydora 46

Poroecus

24,50

Porpostoma 47

Portunus 45

Potamoceros .................. 46

Potomacus ................... 47

Pottsiocles .................. 45

Proboveria ................... 48

Proplectella ................ 50

Prorodon ...................... 44 mimeticus .................. 6

Prorodontidae ............... 8,44

Protocruzia ................. 34,49

Protocymatocylis ................ 50

Protophrya ................... 48

Protorhabdonella ............... 50

Protrichophora ................ 45

Pseudocohnilembidae .......... 20,47

Pseudocohnilembus ............... 47

Pseudogemma .................. 45

Pseudoprorodon ................ 45

Psilotricha .................. 50

Psilotrichidae ............. 37,50

Ptychocylididae .......... 26, 27,50

Ptychocylis ............. 26, 50

Pyxicola .................. 49

Raabella ...................... 48

Remanella...................44 44

Rhabdonella .................. 50

Rhabdonellidae ...........27,50

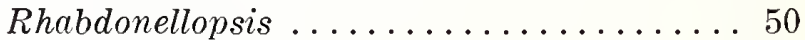

Rhabdophrya ................ 46

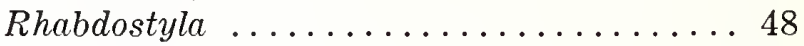

Rhizocaryum ............... 46

Rhizodomus ................... 50

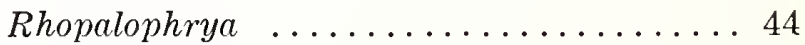

Schizobranchia ................. 46

Schizocalyptra .............. 47

Schizocaryum dogieli .......... 12, 45

Scuticociliatida ........... 20,47,48

Scyphidia ................. 48

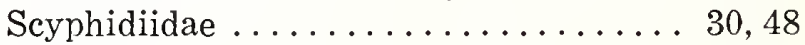

Sepia ...................... 46

Sessilina .................... 29

Sigmocineta ..................... 44

Silenella ovoidea ............ 36, 46 
Sonderia

Spasmostoma

Spathidiidae

8,44

Sphenophrya

Sphenophryidae

$2,40,41,48$

Spirobuetschliella

46

Spirochona

Spirochonidae

31,45

Spirofilidae

$15,36,51$

Spirostomatidae

17,49

Steinella

46

Stenosemella

Stentor

Stentoridae

16,49

Stephanopogon

. 44

Stephanopogonidae

$1,35,44$

Stichotricha

51

Stomatophrya

44

Strobilidiidae

29,50

Strobilidium

Strombidiidae

Strombidium

49,50

Strongylidium

Stylicauda 50

Stylochona 45

Stylochonidae

31,45

Stylonychia 50

Suctorida $1,2,36,39,45$

Swedmarkia

Tachyblaston

Tachysoma 50

Tetrahymenidae 19,47

Thaumatophrya 46

Thecacineta

Thigmophyra

48

Thigmophryidae

$13,22,48$

Thigmotrichida

$2,46,47,48$

Thuricola

Tiarina

Tintinnida

Tintinnidae

$24,27,50$

Tintinnidiidae

24,50

Tintinnidium

Tintinnopsis

50

Tontonia

49

Tracheliidae

10,44

Trachelius

Trachelocerca
Trachelocercidae

$2,9,35,45$

Trachelonema

45

Trachelophyllum .............. 44

Tracheloraphis ................ 45

Trachelostyla ............... 50

Trichodina .................... 49

Trichodinella .................444

Trichodininae .............. 29, 48

Trichodinopsis ................. 48

Trichophrya ................ 45

Trichostomatida ........... 12, 13, 45

Trichotaxis ..................... 50

Trimyema ................. 45

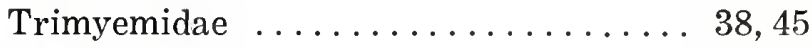

Tripartiella .............. 48,49

Trochilia ................... 44

Trochilioides ................ 44

Trophogemma ................. 46

Undella ..................... 50

Undellidae $\ldots \ldots \ldots \ldots \ldots \ldots \ldots \ldots 27,50$

Undellopsis ................. 50

Urceolaria .................. 48

Urceolariidae ............. 28, 48

Urceolarinae .............. 29,48

Uroleptopsis .................. 50

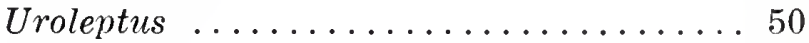

Uronema ..................... 47

Uronematidae ............ 21, 47

Uronychia .................. 50

Uropedalium ................ 47

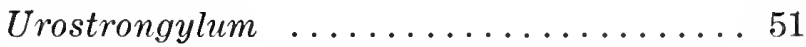

Urostyla .................... 51

Urostylidae .............. 37,51

Urotricha ................... 44

Vaginicola .................. 49

Vaginicolidae ..............28,49

Vasicola ....................... 44

Vauchomia ..................... 49

Vorticella ..................... 49

Vorticellidae ............. 1,30,49

Wailesia ..................... 50

Wangiella ..................... 50

Woodruffia .................. 45

Xystonella .................. 50

Xystonellidae .............26,50

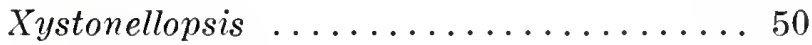

Zonotrichium ................ 44

Zoothamnium ................ 49 


\section{ACKNOWLEDGMENTS}

Preparation of the "Marine Flora and Fauna of the Northeastern United States" is being coordinated by the following Board:

\author{
Coordinator: Melbourne R. Carriker, Systematics- \\ Ecology Program, Marine Biological \\ Laboratory, Woods Hole, Mass. \\ Advisers: Marie B. Abbott, Systematics-Ecology \\ Program. \\ Arthur G. Humes, Boston University Ma- \\ rine Program, and Systematics-Ecology \\ Program. \\ Wesley N. Tiffney, Department of Biology, \\ Boston University, and Systematics- \\ Ecology Program. \\ Ruth D. Turner, Museum of Comparative \\ Zoology, Harvard University, and Syste- \\ matics-Ecology Program.
}

Roland L. Wigley, National Marine Fisheries Service, Woods Hole, Mass.

Robert T. Wilce, Department of Botany, University of Massachusetts, and Systematics-Ecology Program.

The Board established the format for the "Marine Flora and Fauna of the Northeastern United States," invites systematists to collaborate in the preparation of manuals, reviews manuscripts, and advises the Scientific Editor of the National Marine Fisheries Service.

John O. Corliss, Helen T. Loeblich, Jesse C. Thompson, Jr., and Eugene B. Small submitted criticisms, suggestions, and helpful additions for construction of the key. Illustrations were penciled by Arthur C. Borror and were inked by Susan P. Heller. Eva S. Montiero typed the manuscript. Preparation of the manual was supported in part by Project No. 18050 FBW, Federal Water Pollution Control Administration, to Borror, and by Grant GB-24,832 from the National Science Foundation to the Systematics-Ecology Program. A contribution of the Jackson Estuarine Laboratory.

\section{COORDINATOR'S COMMENTS}

Publication of the "Marine Flora and Fauna of the Northeastern United States" is most timely in view of the growing universal emphasis on environmental work and the urgent need for more precise and complete identification of coastal organisms than has been available. It is mandatory, wherever possible, that organisms be identified accurately to species. Accurate scientific names unlock the great quantities of biological information storec in libraries, obviate duplication of research already done, and make possible prediction of attributes of organisms that have been inadequately studied.
Dr. Arthur C. Borror began his systematic investigation of the ciliates of the east coast of the United States in 1959 while pursuing graduate studies at Florida State University, Tallahassee. He moved to the University of New Hampshire in 1961, where he has continued his research on the morphology and ecology of marine ciliates.

Manuals are available for purchase from the Superintendent of Documents, U.S. Government Printing Office, Washington, D.C. 20402. The manuals so far published in the series and their cost per copy are listed below.

COOK, DAVID G., and RALPH O. BRINKHURST. Marine flora and fauna of the Northeastern

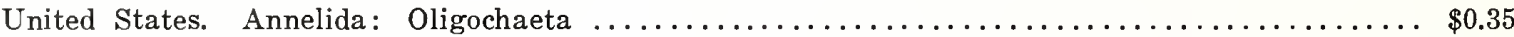

BORROR, ARTHUR C. Marine flora and fauna of the Northeastern United States. Protozoa:

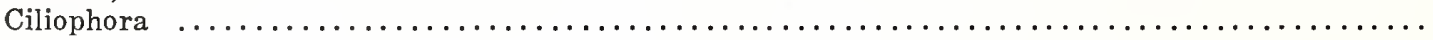


349. Use of abstracts and summaries as communication devices in technical articles. By F. Bruce Sanford. February 1971, iii +11 pp., 1 fig.

350. Research in fiscal year 1969 at the Bureau of Commercial Fisheries Biological Laboratory, Beaufort, N.C. By the Laboratory staff. November 1970, ii + 49 pp., 21 figs., 17 tables.

351. Bureau of Commercial Fisheries Exploratory Fishing and Gear Research Base, Pascagoula, Mississippi, July 1, 1967 to June 30, 1969. By Harvey R. Bullis, Jr., and John R. Thompson. November 1970 , iv +29 pp., 29 figs., 1 table.

352. Upstream passage of anadromous fish through navigation locks and use of the stream for spawning and nursery habitat, Cape Fear River, N.C., 1962-66. By Paul R. Nichols and Darrell E. Louder. October 1970 , iv +12 pp., 9 figs., 4 tables.

356. Floating laboratory for study of aquatic organisms and their environment. By George R. Snyder, Theodore H. Blahm, and Robert J. McConnell. May 1971, iii + 16 pp., 11 figs.

361. Regional and other related aspects of shellfish consumption - some preliminary findings from the 1969 Consumer Panel Survey. By Morton M. Miller and Darrel A. Nash. June 1971, iv + 18 pp., 19 figs., 3 tables, 10 apps. 
UNITED STATES

DEPARTMENT OF COMMERCE

NATIONAL OCEANIC AND ATMOSPHERIC ADMINISTRATION

NATIONAL MIARINE FISHERIES SERVICE

SCIENTIFIC PUBUICATIONS STAFF

ROOM 4 SO

FOURTH CLASS

STH ST

SEATTIE, WA 98105

OFFICIAL BUSINESS
PENN STATE UNIVERSITY LIBRARIES

I.IIIIII)

$\|$ IIIIIIIIIIIIIIIII

A000072018606

U.S.MAIL 